\title{
Photosensitised heterogeneous oxidation kinetics of biomass burning aerosol surrogates by ozone using an irradiated rectangular channel flow reactor
}

\author{
S. M. Forrester and D. A. Knopf \\ Institute for Terrestrial and Planetary Atmospheres/School of Marine and Atmospheric Sciences, Stony Brook University, \\ Stony Brook, New York, USA \\ Correspondence to: D. A. Knopf (daniel.knopf@stonybrook.edu)
}

Received: 6 March 2013 - Published in Atmos. Chem. Phys. Discuss.: 20 March 2013

Revised: 5 June 2013 - Accepted: 7 June 2013 - Published: 9 July 2013

\begin{abstract}
Heterogeneous reaction kinetics involving organic aerosol and atmospheric oxidants such as ozone can be enhanced under visible or UV irradiation in the presence of a photosensitiser, with subsequent implications for the climate, cloud radiative properties, air quality, and source appointment. In this study we report the steady-state reactive uptake coefficient, $\gamma$, of $\mathrm{O}_{3}$ by levoglucosan and 5-nitroguaiacol acting as surrogates for biomass burning aerosol particles, with and without the presence of Pahokee peat acting as a photosensitiser. The reactive uptake has been determined in the dark and as a function of visible and UV-A irradiation and ozone concentration. In addition, $\gamma$ was determined for $1: 1$, $1: 10$, and $1: 100$ by mass mixtures of Pahokee peat and 5nitroguaiacol, and for a 10:1:3 mixture of levoglucosan, Pahokee peat, and 5-nitroguaiacol. We developed a novel irradiated rectangular channel flow reactor (I-RCFR) that was operated under low pressures of about $2-4 \mathrm{hPa}$, and allowed for uniform irradiation of the organic substrates. The I-RCFR was coupled to a chemical ionisation mass spectrometer and has been successfully validated by measuring the kinetics between various organic species and oxidants. $\gamma$ of $\mathrm{O}_{3}$ and levoglucosan in the dark and under visible and UV-A irradiation was determined to be in the range of $(2-11) \times 10^{-6}$ and did not change in the presence of Pahokee peat. The determined $\gamma$ of $\mathrm{O}_{3}$ and 5-nitroguaiacol in the dark was $5.7 \times 10^{-6}$ and was only enhanced under UV-A irradiation, yielding a value of $3.6 \times 10^{-5} \cdot \gamma$ of the $1: 1$ Pahokee peat/5-nitroguaiacol substrate was enhanced under visible and UV-A irradiation to $2.4 \times 10^{-5}$ and $2.8 \times 10^{-5}$, respectively. Decreasing the amount of Pahokee peat in the 5-nitroguaiacol/Pahokee peat
\end{abstract}

substrate resulted in lower values of $\gamma$ under visible irradiation, however, $\gamma$ was consistent under UV-A irradiation regardless of the amount of Pahokee peat. The 10:1:3 mixture by mass of levoglucosan, Pahokee peat, and 5-nitroguaiacol, under both visible and UV-A irradiation yielded $\gamma$ values of $2.8 \times 10^{-5}$ and $1.4 \times 10^{-5}$, respectively. $\gamma$ was determined as a function of photon flux for $\mathrm{O}_{3}$ with the $1: 1 \mathrm{~Pa}$ hokee peat/5-nitroguaiacol substrate, yielding a linear relationship under both visible and UV-A irradiation. $\gamma$ of $\mathrm{O}_{3}$ with the $1: 1$ Pahokee peat/5-nitroguaiacol substrate was determined as a function of ozone concentration and exhibited an inverse dependence of $\gamma$ on ozone concentration, commonly interpreted as a Langmuir-Hinshelwood mechanism. The reactive uptake data have been represented by a Langmuir-type isotherm. From the $\mathrm{O}_{3}$ uptake data under visible irradiation, the following fit parameters have been derived: $k_{\mathrm{s}}=(5.5 \pm 2.7) \times 10^{-19} \mathrm{~cm}^{2} \mathrm{~s}^{-1}$ molecule ${ }^{-1}$ and $K_{\mathrm{O}_{3}}$ $=(2.3 \pm 2.0) \times 10^{-12} \mathrm{~cm}^{3}$ molecule ${ }^{-1}$; and under UV-A irradiation: $k_{\mathrm{s}}=(8.1 \pm 2.0) \times 10^{-19} \mathrm{~cm}^{2} \mathrm{~s}^{-1}$ molecule $^{-1}$ and $K_{\mathrm{O}_{3}}=(1.7 \pm 0.7) \times 10^{-12} \mathrm{~cm}^{3}$ molecule $^{-1}$. The oxidative power, or the product of $\gamma$ and $\left[\mathrm{O}_{3}\right]$, was determined for $\mathrm{O}_{3}$ with the 1:1 Pahokee peat/5-nitroguaiacol substrate and was in the range of $(1.2-26) \times 10^{6}$ molecule $\mathrm{cm}^{-3}$. Atmospheric particle lifetimes were estimated for a $0.4 \mu \mathrm{m}$ 5-nitroguaiacol particle as a function of visible and UV-A irradiation and ozone concentration. 


\section{Introduction}

Condensed phase organic material is ubiquitous in the atmosphere and can constitute a significantly large portion (20-90\%) of the submicron atmospheric aerosol mass fraction (Kanakidou et al., 2005; Zhang et al., 2007; Hallquist et al., 2009). Biomass burning is a large source of trace gases and organic aerosol to the atmosphere, and it has a source strength that is comparable to fossil fuel burning (Crutzen et al., 1979; Logan et al., 1981; Crutzen and Andreae, 1990). Biomass burning aerosol (BBA) can have significant effects on air quality and human health, and it can directly affect the atmosphere through scattering and absorption of radiation, or indirectly through influencing cloud radiative properties by impacting underlying microphysics (Hobbs and Radke, 1969; Ramanathan et al., 2001; Pope et al., 2009; Levin et al., 2010; Dusek et al., 2011; Engelhart et al., 2012).

Although BBA represents a complex mixture of inorganic and water soluble/insoluble organic compounds, some species are common in BBA and can be applied as biomolecular markers for source apportionment of biomass burning plumes (Hawthorne et al., 1988, 1989; Simoneit, 2002; Robinson et al., 2006b; Fu et al., 2012). Two such biomolecular markers are the hemicellulose decomposition product levoglucosan (1,6-anhydro- $\beta$-D-glucopyranose, $\mathrm{C}_{6} \mathrm{H}_{10} \mathrm{O}_{5}$ ) and the substituted phenol 5-nitroguaiacol (2-methoxy-5nitrophenol, $\mathrm{C}_{7} \mathrm{H}_{7} \mathrm{NO}_{4}$ ) (Hawthorne et al., 1988, 1989; Simoneit, 2002; Robinson et al., 2006b; Fu et al., 2012). To assess the aerosol source strength, biomolecular markers employed in apportionment studies should be inert with respect to chemical reaction during atmospheric transport. In the atmosphere, however, BBA particles are exposed to gas phase oxidants such as $\mathrm{O}_{3}$, resulting in multiphase chemical reactions, which can cause chemical and physical modification of the particles, a process known as chemical ageing (Hennigan et al., 2010; Kessler et al., 2010; Hennigan et al., 2011; Knopf et al., 2006, 2011; Shiraiwa et al., 2012). It has been shown that $\mathrm{O}_{3}$ can be photochemically created in BB plumes, with reported concentration levels as high as 100 ppb (Delany et al., 1985; Andreae et al., 1988; Crutzen and Andreae, 1990; Ziemke et al., 2009; Konovalov et al., 2011; Dupont et al., 2012; Martins et al., 2012; Akagi et al., 2013). Therefore, heterogeneous oxidation reactions inside a BB plume can cause chemical modification of particles and biomolecular marker species, potentially having subsequent effects on source apportionment (Robinson et al., 2006b; Lin et al., 2010). Chemical ageing may also enhance aerosol toxicity, as well as yield changes in aerosol hygroscopicity, affecting cloud formation processes (Finlayson-Pitts and Pitts, 2000; Maria et al., 2004; Rudich et al., 2007; Andreae, 2009; Jimenez et al., 2009; Hennigan et al., 2011; Wang and Knopf, 2011). It has been shown recently that there can be significant degradation and volatilisation of typical BBA species such as levoglucosan, abietic acid, and 5-nitroguaiacol through heterogeneous oxidation reactions (Hennigan et al., 2010;
Kessler et al., 2010; Knopf et al., 2011; Shiraiwa et al., 2012). The reactive uptake coefficient, $\gamma$, or the probability that a gas-to-particle collision results in loss of that gas molecule due to reaction, of $\mathrm{O}_{3}$ with levoglucosan and 5nitroguaiacol can be on the order of $10^{-5}$ in the absence of irradiation (Knopf et al., 2011). The corresponding oxidative powers $\left(\gamma \cdot\left[\mathrm{O}_{3}\right]\right)$ can be on the order of $3.3 \times 10^{7}$ and $2.0 \times 10^{8}$ molecule $\mathrm{cm}^{-3}$, respectively, assuming $100 \mathrm{ppb}$ of $\mathrm{O}_{3}$ in a BB plume (Knopf et al., 2011). Compared to the oxidative power of $\mathrm{OH}$ with levoglucosan, $5.9 \times 10^{6}$ assuming $\gamma_{\mathrm{OH}}=0.52$ and $[\mathrm{OH}]=0.46 \mathrm{ppt}$ (Yokelson et al., 2009; Slade and Knopf, 2013), heterogeneous reactions of $\mathrm{O}_{3}$ with compounds typical of BBA and thus particle and species degradation could be significant; however, volatilisation of condensed phase species is expected to be much less for reactions involving $\mathrm{O}_{3}$ compared to $\mathrm{OH}$ (Slade and Knopf, 2013). In summary, it is highly likely that BBA particles undergo chemical ageing by $\mathrm{O}_{3}$ during atmospheric transport, with subsequent implications for source apportionment calculations.

Chemical ageing of BBA by gas phase oxidants can be amplified due to the presence of a photosensitiser. A photosensitiser is a light-absorbing compound that can further enhance heterogeneous kinetics through photosensitive interactions with other species (George et al., 2005; Jammoul et al., 2008; Sosedova et al., 2011). A photosensitising compound can absorb radiation and transfer its excitation energy to a neighbouring molecule that might not have otherwise absorbed radiation (Vione et al., 2006; Hoffmann, 2008; Gómez-Alvarez et al., 2012). This activated molecule can then undergo other processes such as oligomerisation, HONO formation, or chemical ageing (Gómez-Alvarez et al., 2012). Humiclike substances (HULIS) are commonly present in BBA and have been shown to possess photosensitive properties (Facchini et al., 2000; Mayol-Bracero et al., 2002; Gelencsér et al., 2003; Lukács et al., 2007; Schmidl et al., 2008a,b; Fors et al., 2010; Konovalov et al., 2012). The presence of HULIS in BBA may enhance degradation of biomolecular markers if they are able to absorb the excitation energy of the photosensitiser and subsequently react more efficiently with atmospheric oxidants. Concentrations of HULIS can be highly variable in BB smoke, i.e. 0.6-5.8 wt \% of HULIS in wood combustion smoke compared to 1.6-21.2 wt \% from burning leaves (Schmidl et al., 2008a,b). The effect of varying the amount of photosensitiser in a photosensitised reactive uptake measurement has not been explored in detail.

It has been shown experimentally that phenols can efficiently quench the excited triplet state of a photosensitiser, such as an aromatic carbonyl compound, in solution (Canonica et al., 1995; Anastasio et al., 1997; Canonica et al., 2000). However, it is expected that these types of reactions may be even more efficient at the surface of aerosol particles due to enhanced light intensity at the surface (Nissenson et al., 2006). Although phenolic and polyphenolic compounds are ubiquitous in the atmosphere, they can be 
significantly enhanced in BB plumes, and have been suggested as tracers for BBA sources (Rogge et al., 1998; Fine et al., 2001). Recent studies have shown that reactive uptake of gas phase oxidants by adsorbed phenolic and polyphenolic compounds such as catechols, gentisic acid, tannic acid, 4-phenoxyphenol, and phenol in the presence of a photosensitiser can be significantly enhanced when exposed to ultraviolet (UV) or visible (VIS) radiation compared to dark conditions (George et al., 2005; Jammoul et al., 2008; Net et al., 2010; Sosedova et al., 2011).

Previous studies have observed that $\gamma$ can have a linear dependence on VIS and UV photon flux, but some measurements were limited in the VIS photon flux intensity compared to the sun's total VIS irradiance (Stemmler et al., 2006; Jammoul et al., 2008; Brigante et al., 2008; D'Anna et al., 2009; Baduel et al., 2011; Sosedova et al., 2011; Zelenay et al., 2011). Previous studies have also shown that the uptake of gas phase oxidants may follow a Langmuir-Hinshelwood (LH) type reaction mechanism, where the oxidant first adsorbs on the organic substrate and subsequently reacts, yielding $\gamma$ values that are reduced at high oxidant concentrations (Stemmler et al., 2007; Jammoul et al., 2008; Brigante et al., 2008; D'Anna et al., 2009; Net et al., 2010; Baduel et al., 2011; Sosedova et al., 2011; Zelenay et al., 2011). A recent modelling study by Konovalov et al. (2012) indicated that there may be a positive feedback between the $\mathrm{O}_{3}$ loss rate and $\mathrm{O}_{3}$ mixing ratio because of this inverse dependence of $\gamma$ on $\mathrm{O}_{3}$ concentration (Konovalov et al., 2012).

This study will explore the effect of using the humic acid Pahokee peat (PP) as a proxy for atmospheric HULIS acting as a photosensitiser on $\gamma$ of $\mathrm{O}_{3}$ with solid films of levoglucosan (LEV) and 5-nitroguaiacol (NG) when exposed to UV and VIS radiation. We employ a novel irradiated rectangular channel flow reactor (I-RCFR) coupled to a custombuilt chemical ionisation mass spectrometer (CIMS) to determine photosensitised heterogeneous kinetics. The advantage of this approach is the capability to uniformly irradiate the organic substrate and conduct reactive uptake measurements at atmospherically relevant $\mathrm{O}_{3}$ concentrations and at low pressures, thereby decreasing diffusion-limiting effects. The presented study will also explore the effect of varying the amount of photosensitiser by investigating $1: 1$, $1: 10$, and 1:100 mixtures by mass of PP and NG. We will also investigate a 10:1:3 mixture by mass of LEV, NG, and PP. Although we do not know the triplet redox potential of PP and NG, NG is expected to efficiently absorb excitation energy from PP due to its phenolic structure, and therefore have enhanced reactivity towards ozone. Previous studies suggest that photosensitisers such as methylene blue, benzophenone, 3'-methoxyacetophenone, and 2acetonaphthone possess triplet redox potentials larger than $+1.10 \mathrm{~V}$ (vs. normal hydrogen electrode) (Canonica et al., 2000; Sosedova et al., 2011), whereas, e.g., 4-nitrophenol possesses redox potentials smaller than at $-1.02 \mathrm{~V}$ (vs. Ag electrode) (Silvester et al., 2006). This indicates the likeli- hood that triplet excited states of PP can accept electrons from NG, allowing this energy transfer. We also investigate the effect of irradiation intensity on $\gamma$. This study employs a photon flux similar to that received by the sun for both VIS $\left(\Phi_{\mathrm{p}}=1.0 \times 10^{17}\right.$ photons $\left.\mathrm{cm}^{-2} \mathrm{~s}^{-1}\right)$ and UV$\mathrm{A}\left(\Phi_{\mathrm{p}}=5.6 \times 10^{15}\right.$ photons $\left.\mathrm{cm}^{-2} \mathrm{~s}^{-1}\right)$ radiation (Gueymard et al., 2002). Lastly, we will also explore the effect of $\mathrm{O}_{3}$ concentration on $\gamma$ at atmospherically relevant oxidant concentrations.

\section{Experimental}

\subsection{Apparatus}

Uptake experiments were conducted using an I-RCFR with controlled irradiance coupled to CIMS based on previous setups (Fig. 1) (Knopf et al., 2007, 2011). The I-RCFR is rectangular in shape, allowing us to study the reactivity of a substrate with dimensions of $9.0 \times 14.9 \mathrm{~cm}^{2}$. Either a quartz trough or a sand-blasted glass block can be inserted to study the uptake of gas phase oxidants by liquids or highly viscous/amorphous solid films, respectively. The bottom of the flow reactor is equipped with a cooling jacket to control the temperature of the uptake experiments. Temperatures reported in this study are of the substrate surface. This was determined with a thermocouple directly contacting the glass block while the flow reactor was under low pressure and gas flow was present. Temperatures of the gas were also recorded to determine the mean thermal velocity of the gas molecules. The temperature measurements were performed in the dark and under VIS and UV irradiation.

The top cover of the flow reactor is made of quartz glass to allow maximum transmission ( $90 \%$ for VIS and UV) of irradiance to the reactive substrate. The quartz is covered with black vinyl for the dark reactive uptake measurements. The distance between the reactive surface and the inside of the cover is $7 \mathrm{~mm}$. The $\mathrm{O}_{3}$ enters the flow reactor through a $1 / 8^{\prime \prime}$ outer diameter movable injector with a u-shaped end, resulting in two gas flow exits to enhance lateral mixing of the $\mathrm{O}_{3}$ downstream of the flow reactor. Carrier gases were introduced through two inlets at the back of the flow reactor and allowed to thoroughly mix laterally by use of a mixing barrier.

\subsection{Uptake measurements}

The pseudo-first-order loss of the oxidant to the organic substrate was determined using two different methods. The first method employs monitoring the loss of the gas phase species as the injector was instantaneously pulled back 10 or $12 \mathrm{~cm}$ over the reactive substrate. The change in the gas phase oxidant's concentration was then monitored as a function of exposure time $(\sim 10 \mathrm{~min})$. The steady-state $\mathrm{O}_{3}$ signal is used for calculation of $\gamma$. In some instances, e.g. for validation of literature values, we used the initial drop in the $\mathrm{O}_{3}$ signal to 


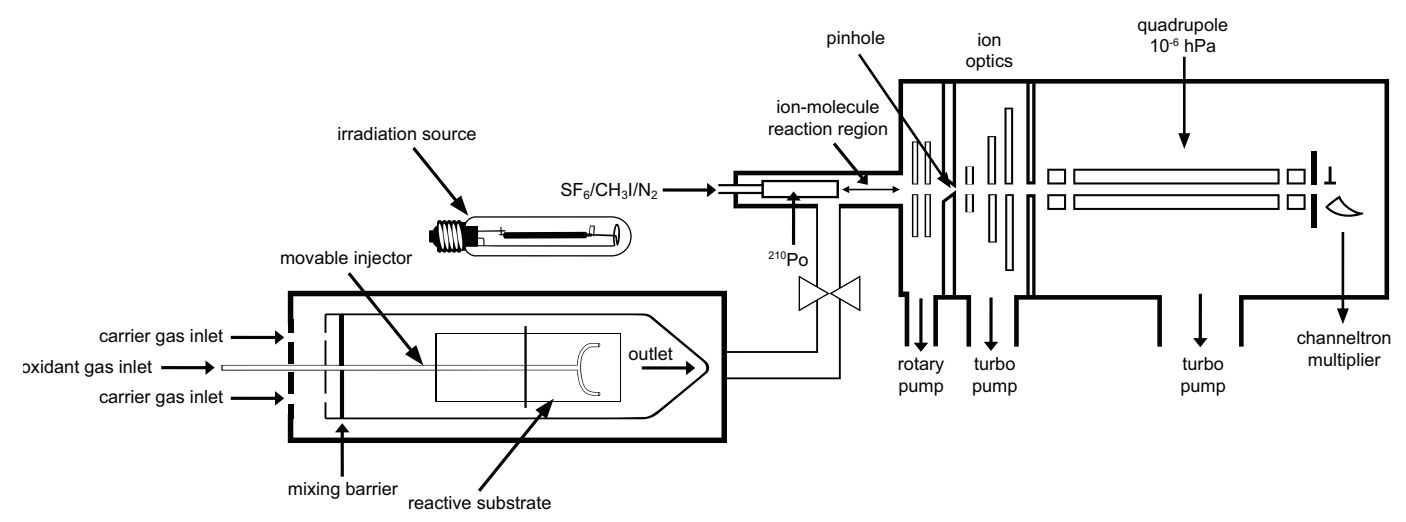

Fig. 1. Schematic representation (not to scale) of the irradiated rectangular channel flow reactor (I-RCFR) coupled to the chemical ionisation mass spectrometer. Irradiation source distance above the I-RCFR is adjustable.

calculate $\gamma$. The second method monitors the loss of the gas phase species as the injector is pulled back over the organic substrate in increments of $3 \mathrm{~cm}$ until reaching $12 \mathrm{~cm}$. These methods will be termed pullback and stepwise, respectively, for the remainder of the manuscript. At least 6 independent experiments were conducted for each investigated species or mixture. For each pullback experiment a freshly prepared organic substrate was applied. For the stepwise method, a fresh substrate was used at the beginning of the experiment, but was not changed for each stepwise increment during the experiment.

\subsection{Irradiation source}

The VIS irradiation source used is a $400 \mathrm{~W}$ GrowBright highpressure sodium (HPS) lamp, fit inside an air-coolable reflector (HTG Supply). The UV irradiation source used is a $400 \mathrm{~W}$ Eliminator high-pressure mercury vapour blacklight bulb, also fit inside an air-coolable reflector. The lamps are positioned above the flow reactor in such a way that they can be moved closer or farther away, allowing for a change in the photon flux reaching the reactive substrate. The light sources are positioned directly above the flow reactor so that the zenith angle is $0^{\circ} \mathrm{C}$. The spectral irradiance reaching the reactive substrate was determined using a USB 2000 spectrometer coupled to a $50 \mu \mathrm{m}$ optical fiber (Ocean Optics). The spectrometer was calibrated using an HL-2000-CAL calibrated tungsten lamp (Ocean Optics). A UV-VIS neutral density filter with an optical density of 3.0 and a wavelength range of 200-700 nm was used between the optical fiber and the irradiation source to avoid saturation of the spectrometer detector. The measurements were performed with the quartz cover between the fiber optics and the irradiation source. For the UV irradiance measurements, a UV bandpass filter with a centre wavelength of $360 \mathrm{~nm}$ was used to eliminate all wavelengths except the main peak at $365.7 \mathrm{~nm}$. This filter was positioned on top of the quartz cover during UV uptake experiments to eliminate possible influences from VIS irradiation.

\subsection{Oxidant generation, detection, and flow conditions}

The gases $\mathrm{N}_{2}$ and $\mathrm{He}$ were first passed through a carbon filter (Supelco, Supelcarb HC) and a Drierite trap cooled with liquid nitrogen to remove any possible organic contamination. $\mathrm{O}_{2}$ was passed through a Drierite trap cooled by a liquid ethanol/dry ice mixture. $\mathrm{O}_{3}$ was generated by passing a flow of $\mathrm{O}_{2}$ over a UV source (Jelight, model \#600) before entering the flow reactor. The flow of the $\mathrm{O}_{2} / \mathrm{O}_{3}$ mixture varied between 1 and $5 \mathrm{~cm}^{3} \mathrm{~min}^{-1}$ at standard temperature and pressure (STP). A He gas carrier flow of about $50 \mathrm{~cm}^{3} \mathrm{~min}^{-1}$ STP entered the flow reactor and was allowed to thoroughly mix laterally. Typical flow velocities inside the I-RCFR were $60-65 \mathrm{~cm} \mathrm{~s}^{-1}$. This resulted in Reynolds numbers of about 0.04 , indicating laminar flow conditions. $\mathrm{O}_{3}$ was detected as $\mathrm{O}_{3}^{-}(m / z=48)$ by the mass spectrometer after chemical ionisation by $\mathrm{SF}_{6}^{-}(m / z=146) . \mathrm{SF}_{6}^{-}$was generated by passing a trace amount of $\mathrm{SF}_{6}$ in about $1 \mathrm{Lmin}^{-1} \mathrm{STP} \mathrm{N}_{2}$ through a ${ }^{210} \mathrm{Po}$ source (Knopf et al., 2005, 2011). $\mathrm{O}_{3}$ concentrations used in these reactive uptake measurements ranged from $1.7 \times 10^{11}$ to $1.9 \times 10^{12}$ molecule $\mathrm{cm}^{-3}$, representing 7 $75 \mathrm{ppb}$. Experiments were conducted at $2-3 \mathrm{hPa}$.

For validation purposes, the uptake of $\mathrm{NO}_{3}$ radicals by linoleic acid (cis,cis-9,12-octadecadienoic acid) was measured. $\mathrm{NO}_{3}$ was generated by thermal decomposition of $\mathrm{N}_{2} \mathrm{O}_{5}$, which was generated through the gas phase reaction of $\mathrm{NO}_{2}$ with excess $\mathrm{O}_{3}$, as discussed in detail in our previous work (Knopf et al., 2006, 2011). $\mathrm{NO}_{3}$ was detected as $\mathrm{NO}_{3}^{-}$ after chemical ionisation by $\mathrm{SF}_{6}^{-}$or $\mathrm{I}^{-}$. $\mathrm{I}^{-}$was generated by passing a trace amount of $\mathrm{CH}_{3} \mathrm{I}$ in about $1 \mathrm{Lmin}^{-1}$ STP $\mathrm{N}_{2}$ through a ${ }^{210}$ Po source (Knopf et al., 2006, 2011). 


\subsection{Substrate preparation}

Pure PP substrates were prepared using a $1 \mathrm{mg} \mathrm{mL}^{-1}$ aqueous solution. PP only partially dissolves in water, leaving some particulate matter suspended in the solution. Pure LEV substrates were prepared using a $1.00 \mathrm{wt} \%$ aqueous solution, and pure NG substrates were prepared using a $1.00 \mathrm{wt} \%$ solution in methanol. One: one $(1: 1)$ by mass PP/LEV substrates were prepared as a $1.00 \mathrm{wt} \%$ aqueous solution, and $1: 1,1: 10$, and $1: 100$ by mass PP/NG substrates were prepared as $1.00 \mathrm{wt} \%$ solutions in methanol. Ten: one: three $(10: 1: 3)$ by mass LEV/PP/NG substrates were prepared as a 1.00 or $2.00 \mathrm{wt} \%$ solutions in methanol. Organic solutions were deposited on the glass block in $\sim 0.6 \mathrm{~mL}$ increments, and solvents were allowed to completely evaporate in a particle free environment. The thickness of the organic film is estimated to be $\sim 0.2-0.4 \mu \mathrm{m}$ based on the amount of applied solution. Evaporation of the organic substrate under the experimental conditions may be possible, but is assumed to be of minor importance according to estimations of the evaporative flux (Cussler, 2010). This is corroborated by visually insignificant changes of the organic substrates after an uptake experiment, similar to previous findings (Knopf et al., 2011; Slade and Knopf, 2013). Continuous evaporation of significant amounts of organic molecules would result in a continuous supply of unreacted surface sites, not supported by our findings of an LH type reaction mechanism, as described below.

\subsection{Absorbance measurements}

Absorbance measurements were conducted using a Cary 1 UV-VIS spectrophotometer. A $1 \mathrm{mg} \mathrm{mL}^{-1}$ aqueous solution of PP was centrifuged to remove particulate matter suspended in the solution. The absorbance of a $1 \mathrm{wt} \%$ aqueous solution of LEV was measured, but the results are not reported due to a complete lack of absorbance in the 300$700 \mathrm{~nm}$ wavelength regime. The absorbance of NG was determined by dissolving in both a $0.01 \mathrm{M} \mathrm{HCl}$ or a $0.01 \mathrm{M}$ $\mathrm{NaOH}$ solution to account for effects of solution $\mathrm{pH}$ on absorbance. The effect of changing the solution $\mathrm{pH}$ on the uptake of $\mathrm{O}_{3}$ was not explored in this study.

\subsection{Chemicals}

Listed below are the chemicals, the corresponding purities, and manufacturer used in our studies: $\mathrm{He}$ (UHP), $\mathrm{N}_{2}$ (UHP), $\mathrm{O}_{2}$ (UHP), and $\mathrm{SF}_{6}(99.998 \%)$, all acquired from Praxair; 2-methoxy-5-nitrophenol (97\%), 1,6-anhydro$\beta$-D-glucopyranose (99\%), cis-9-octadecenoic acid (99\%), cis-9,cis-12-octadecadienoic acid (97\%), and methanol (99.9\%), all acquired from VWR; canola oil (not determined) and Pahokee peat humid acid reference 1R103H (International Humic Substances Society). Millipore water (re- sistivity $>18.2 \mathrm{M} \Omega \mathrm{cm}$ ) was used for preparation of aqueous solutions.

\section{Results and discussion}

\subsection{Light source characterisation}

The spectral irradiance of the light sources as well as a standard solar spectrum tilted $37^{\circ}$ from the sun, as given by the American Society for Testing and Materials (Gueymard et al., 2002), are shown in Fig. 2. The total irradiances from the sun are $1.0 \times 10^{17}$ photons $\mathrm{cm}^{-2} \mathrm{~s}^{-1}$ from 400 to $700 \mathrm{~nm}$, and $5.6 \times 10^{15}$ photons $\mathrm{cm}^{-2} \mathrm{~s}^{-1}$ from 300 to $400 \mathrm{~nm}$. The total irradiance for the visible lamp integrated from 400 to $700 \mathrm{~nm}$ is $5.9 \times 10^{17}$ photons $\mathrm{cm}^{-2} \mathrm{~s}^{-1}$ at a distance of $7.6 \mathrm{~cm}$, and the total irradiance for the UV lamp integrated from 300 and $400 \mathrm{~nm}$ is $8.1 \times 10^{15}$ photons $\mathrm{cm}^{-2} \mathrm{~s}^{-1}$ at a distance of $5.1 \mathrm{~cm}$. As shown in Fig. 2, the bulk of the photon flux density for the visible lamp lies between 550 and $650 \mathrm{~nm}$. However, previous studies use fluorescent lamps which have significant photon flux from 400 to $500 \mathrm{~nm}$ (Jammoul et al., 2008; D'Anna et al., 2009). Furthermore, the sun emits irradiation continually in the visible wavelength regime, indicating that our VIS light source may lack shorter wavelength irradiation compared to the sun. Also shown in Fig. 2, the photon flux from the UV irradiation source peaks from 362 to $372 \mathrm{~nm}$. However, the sun continually emits irradiation in the UV-A wavelength regime, again indicating that our UV light source may lack shorter wavelength irradiation compared to the sun.

The total irradiance was also measured as a function of distance from the reactive substrate for each of the lamps, as shown in Fig. 3. Our setup allows for the variation of the total VIS and UV photon flux by at least an order of magnitude.

\subsection{Derivation of reactive uptake coefficient}

The reactive uptake coefficient, $\gamma$, is derived using the method developed by Knopf and coworkers (Knopf et al., 2007). As mentioned above, the loss of ozone is measured as the injector is pulled back over a known distance of the organic substrate. Assuming first-order kinetics, we can describe the relationship between distance and concentration as follows:

$C(l)=C_{0} \exp \left(-\frac{k_{\mathrm{obs}} l}{v_{\mathrm{avg}}}\right)$,

where $C(l)$ is the $\mathrm{O}_{3}$ concentration at position $l, l$ is the length of the reactive substrate exposed to $\mathrm{O}_{3}, C_{0}$ is the concentration at $l=0, v_{\text {avg }}$ is the average flow velocity, and $k_{\text {obs }}$ is the observed first-order reaction rate constant. We determine $k_{\mathrm{obs}}$ as the slope of the logarithmic change in the normalised $\mathrm{O}_{3}$ signal as a function of reaction time, $t=l / v_{\text {avg }}$, as shown in Fig. 4. Efficient reactive uptake of $\mathrm{O}_{3}$ can result in concentration gradients close to the substrate surface, and 


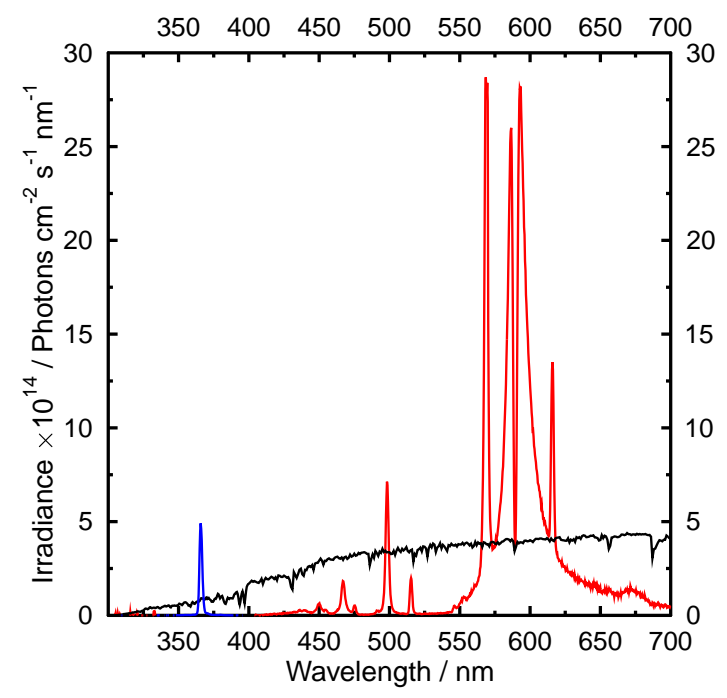

Fig. 2. Spectral irradiance of the VIS and UV irradiation sources used in this study are presented as red and blue lines, respectively. The black line indicates the spectral irradiance of the sun.

thus diffusion effects must be considered. The diffusion coefficient of $\mathrm{O}_{3}$ in $\mathrm{He}$ is taken as $394 \mathrm{Torrcm}^{2} \mathrm{~s}^{-1}$ at $298 \mathrm{~K}$ (Moise and Rudich, 2000). Correction for concentration gradients in the vertical direction and in the direction of the bulk gas flow is performed by numerical analysis of the laboratory data following the method described by Knopf et al. (2007). The analysis uses iterative measures to obtain the first-order reaction rate constant, $k_{\mathrm{w}}^{1 \mathrm{st}}$ from the experimentally determined $k_{\text {obs. }} \gamma$ is derived according to the first-order wall loss rate constant (Hanson, 1998; Knopf et al., 2007):

$\frac{1}{\gamma}=\frac{c A}{4 k_{\mathrm{w}}^{1 \mathrm{st}} V}+\frac{1}{2}$

where $A$ is the geometric surface area of the organic substrate, $V$ is the volume of the gas above the reactive substrate, $k_{\mathrm{w}}^{1 \text { st }}$ is the first-order wall loss rate constant, and $c$ is the thermal molecular speed of $\mathrm{O}_{3}$. Correction for diffusion is on average $<15 \%$ for the measured uptake coefficients.

The $\gamma$ values reported in this study are steady-state $\gamma$ values, meaning they were calculated from a steady $\mathrm{O}_{3}$ signal. The initial $\gamma$ was also determined for comparison with some literature values, whereby the maximum drop in the $\mathrm{O}_{3}$ signal was used to calculate $\gamma$.

\subsection{Validation}

To validate the I-RCFR we measured $\gamma$ of oleic acid (cis-9octadecenoic acid, $\mathrm{C}_{18} \mathrm{H}_{34} \mathrm{O}_{2}$ ), canola oil, levoglucosan, 5nitroguaiacol, and PP (under dark and UV irradiation conditions) with $\mathrm{O}_{3}$ and linoleic acid with $\mathrm{NO}_{3}$, as shown in Table 1. The uptake of $\mathrm{O}_{3}$ by liquid and solid oleic acid is in agreement with previous studies within experimental uncertainty (Moise and Rudich, 2002; Zahardis and Petrucci,

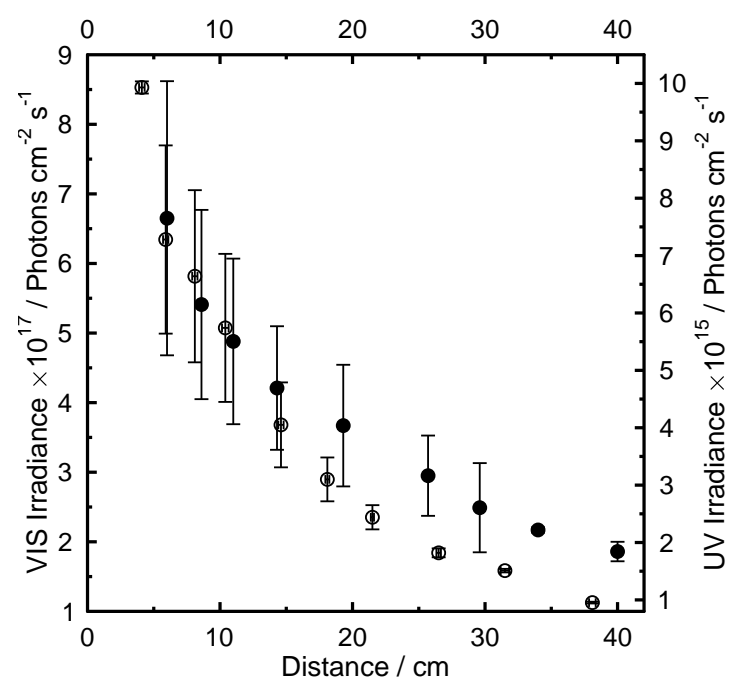

Fig. 3. Total irradiances for the VIS and UV irradiation sources as a function of lamp distance from the organic substrate are shown as closed and open circles, respectively. The open circles refer to the right $\mathrm{y}$-axis. Error bars denote $1 \sigma$ of the mean irradiance and the mean distance.

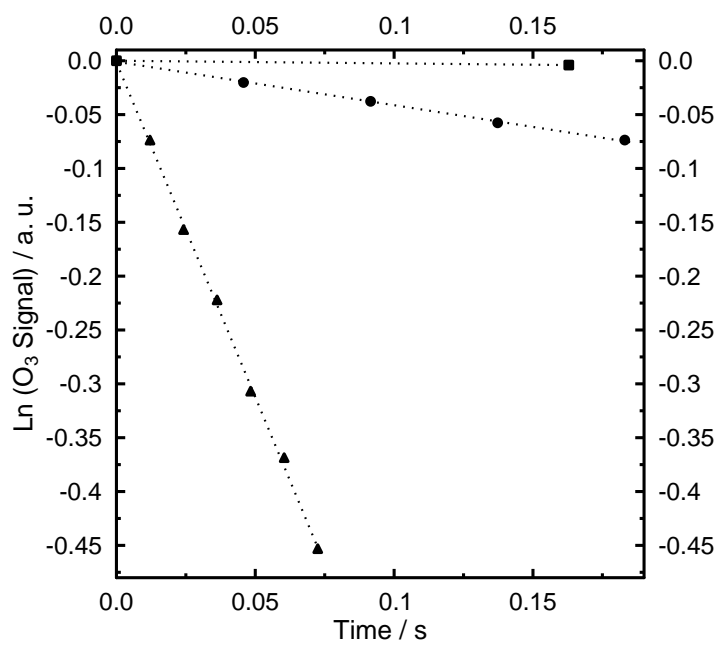

Fig. 4. Natural logarithm of the normalised ozone signal as a function of reaction time. Squares, circles, and triangles denote exemplary reactive uptake data of $\mathrm{O}_{3}$ by a blank glass block, the 1:1 by mass PP/NG substrate, and canola oil, respectively. Dotted lines represent linear fits of the data from which the observed first-order rate constants are determined.

2007). The uptake of $\mathrm{NO}_{3}$ by linoleic acid is in agreement with a study by Zhao et al. (2011). The uptake of $\mathrm{O}_{3}$ by canola oil is, within experimental uncertainty, in agreement with a previous study by Knopf et al. (2007) that utilised an RCFR. The preceding reactive uptake measurements were performed using the stepwise method. The uptake of $\mathrm{O}_{3}$ by LEV is in agreement with our previous study using a rotating-wall flow-tube reactor (Knopf et al., 2011). 
Table 1. Comparison of reactive uptake coefficients, $\gamma$, determined in this study with literature values for various liquid and solid organic substrates and gas phase oxidants. Uncertainty is $\pm 1 \sigma$.

\begin{tabular}{lllll}
\hline Substrate & Oxidant & $T / \mathrm{K}$ & $\gamma^{\mathrm{a}}$ & $\gamma$ \\
\hline Oleic Acid $^{\mathrm{h}}$ & $\mathrm{O}_{3}$ & 293 & $(6.5 \pm 1.2) \times 10^{-4}$ & $(7.5-73) \times 10^{-4 \mathrm{~b}}$ \\
Oleic Acid $^{\mathrm{h}}$ & $\mathrm{O}_{3}$ & 273 & $(5.8 \pm 2.5) \times 10^{-5}$ & $(5.2 \pm 0.1) \times 10^{-5 \mathrm{c}}$ \\
Canola Oil $^{\mathrm{h}}$ & $\mathrm{O}_{3}$ & 298 & $(6.2 \pm 0.6) \times 10^{-4}$ & $(6.5-9.3) \times 10^{-4 \mathrm{~d}}$ \\
Linoleic Acid $^{\mathrm{h}}$ & $\mathrm{NO}_{3}$ & 298 & $(0.28 \pm 0.25)$ & $(0.53 \pm 0.12)^{\mathrm{e}}$ \\
Pahokee Peat (dark) $^{\mathrm{i}}$ & $\mathrm{O}_{3}$ & 293 & $(3.5 \pm 2.1) \times 10^{-6}$ & $(3.6 \pm 1.9) \times 10^{-6 \mathrm{f}}$ \\
${\text { Pahokee Peat }(\mathrm{UV})^{\mathrm{i}}}^{\mathrm{j}}$ & $\mathrm{O}_{3}$ & 296 & $(1.7 \pm 0.5) \times 10^{-5}$ & $(5.5 \pm 1.4) \times 10^{-5 \mathrm{f}}$ \\
Levoglucosan $\left(\right.$ dark) $^{\mathrm{j}}$ & $\mathrm{O}_{3}$ & 293 & $(1.7 \pm 1.5) \times 10^{-5}$ & $(1.3 \pm 1.2) \times 10^{-5 \mathrm{~g}}$ \\
5-Nitroguaiacol (dark) & $\mathrm{O}_{3}$ & 293 & $(1.0 \pm 0.4) \times 10^{-5}$ & $(8.3 \pm 6.7) \times 10^{-5 \mathrm{~g}}$ \\
\hline
\end{tabular}

${ }^{a}$ This study. ${ }^{b}$ Zahardis and Petrucci (2007). ${ }^{c}$ Moise and Rudich (2002). ${ }^{d}$ de Gouw and Lovejoy (1998). ${ }^{e}$ Zhao et al. (2011). ${ }^{\mathrm{f}}$ D'Anna et al. (2009). ${ }^{\mathrm{g}}$ Knopf et al. (2011). ${ }^{\mathrm{h}} \gamma$ values were determined using the stepwise method. ${ }^{\mathrm{i}} \gamma$ values were determined from the steady-state $\mathrm{O}_{3}$ signal. ${ }^{j} \gamma$ values were determined using initial drop in $\mathrm{O}_{3}$ signal (see text for more details).

The reactive uptake coefficient of $\mathrm{O}_{3}$ with NG is very close to the study by Knopf et al. (2011), and the minor difference may be due to differences in the morphology of the organic substrate surfaces. It is important to note that the $\gamma$ values of LEV and $\mathrm{NG}$ with $\mathrm{O}_{3}$ were determined using the initial drop of the $\mathrm{O}_{3}$ signal, as in the previous study. Steady-state reactive uptake of $\mathrm{O}_{3}$ by PP under dark conditions is in agreement with a study by D'Anna et al. (2009). Under UV irradiation, however, the steady-state reactive uptake of $\mathrm{O}_{3}$ is lower than previously determined by D'Anna et al. (2009). This can be attributed to a lower total irradiance reaching the substrate, i.e. $8.1 \times 10^{15}$ photons $\mathrm{cm}^{-2} \mathrm{~s}^{-1}$ in this study compared to $2.4 \times 10^{16}$ photons $\mathrm{cm}^{-2} \mathrm{~s}^{-1}$ applied by D'Anna et al. (2009). The authors have determined that decreasing the photon flux causes $\gamma$ to decrease; thus a lower $\gamma$ in our study can be expected.

\subsection{Reactive uptake of ozone}

\subsubsection{Dark experiments}

Steady-state reactive uptake coefficients of $\mathrm{O}_{3}$ were determined in complete darkness, under dry conditions, and with atmospherically relevant $\mathrm{O}_{2}$ levels. The temperature of the organic substrate was $20.0^{\circ} \mathrm{C}$. Under these conditions each substrate can be assumed to be in a highly viscous or amorphous solid state (Mikhailov et al., 2009; Knopf et al., 2011). All dark experiments were performed using the pullback method. As shown in Table 2, $\gamma$ of the LEV substrate is $(3.6 \pm 2.7) \times 10^{-6}$. Such a low $\gamma$ can be expected when considering the low reactivity of the gas phase reaction between $\mathrm{O}_{3}$ and alcohols (Atkinson and Carter, 1984). Steadystate-derived $\gamma$ of NG is $(5.7 \pm 2.5) \times 10^{-6}$, about a factor of 2 lower compared to $\gamma$ determined by applying the initial drop in the $\mathrm{O}_{3}$ signal. The PP substrate yielded a $\gamma$ of $(3.5 \pm 2.1) \times 10^{-6}$, which is in agreement with the value reported by D'Anna et al. (2009). $\gamma$ obtained from the $1: 1$
PP/LEV substrate is similar to $\gamma$ determined from the individual LEV and PP substrates, within experimental error. $\gamma$ derived from the $1: 1,1: 10$, and $1: 100 \mathrm{PP} / \mathrm{NG}$ substrates are all similar to $\gamma$ determined from the individual NG and PP substrates, within experimental error. $\gamma$ of the $10: 1: 3$ LEV/PP/NG substrate exhibited a higher uncertainty, and the resulting $\gamma$ values are similar to that of the individual substrates within the experimental error. The larger uncertainty may be caused by differences in surface composition of the organic substrate.

\subsubsection{Visible irradiation experiments}

Steady-state $\gamma$ values measured in the presence of VIS irradiation were conducted under dry conditions, with atmospherically relevant $\mathrm{O}_{2}$, and with substrate temperatures of $23^{\circ} \mathrm{C}$. Most experiments were conducted using the pullback method; however, some of the experiments using the $1: 1 \mathrm{PP} / \mathrm{NG}$ substrate were conducted with the stepwise method for comparison. These two methods yielded similar $\gamma$ values, within experimental error. As shown in Table 2, $\gamma$ for the pure PP solution is enhanced by more than a factor of 2 when exposed to VIS irradiation. This is expected due to the photosensitive properties of humic acid, and is similar to the effects observed by D'Anna et al. (2009). However, the enhancement in $\gamma$ determined here is smaller than that reported by D'Anna et al. (2009), which may be due to differences in the spectral distribution of the irradiation source used in this study. As shown in Fig. 5, PP absorbs radiation more strongly at lower visible wavelengths, but the visible irradiation source used in our study provides the strongest irradiation between 550 and $650 \mathrm{~nm}$. The uptake of $\mathrm{O}_{3}$ by the pure LEV and NG substrates yields no enhancement when exposed to VIS irradiation. As stated previously, LEV does not absorb radiation in the experimental wavelength regime. As shown in Fig. 5, NG absorbs only at wavelengths smaller than $400 \mathrm{~nm}$ under acidic conditions 
Table 2. Steady-state reactive uptake coefficients, $\gamma$, of organic substrates representative of BBA compounds with $\mathrm{O}_{3}$ under dry conditions and with atmospherically relevant $\mathrm{O}_{2}$ levels. $\gamma$ was determined in the dark and under VIS and UV irradiation. $\mathrm{O}_{3}$ concentrations ranged between $3.5 \times 10^{11}$ and $6.0 \times 10^{11}$ molecule $\mathrm{cm}^{-3}$, and substrate temperatures ranged between 20 and $23^{\circ} \mathrm{C}$. Uncertainty is $\pm 1 \sigma$.

\begin{tabular}{llll}
\hline Substrate & $\gamma_{\text {dark }} \times 10^{-6}$ & $\gamma_{\text {VIS }} \times 10^{-6}$ & $\gamma_{\text {UV }} \times 10^{-5}$ \\
\hline Pahokee Peat & $(3.5 \pm 2.1)$ & $(8.6 \pm 0.8)$ & $(1.7 \pm 0.5)$ \\
Levoglucosan & $(3.6 \pm 2.7)$ & $(4.3 \pm 2.1)$ & $(0.6 \pm 0.4)$ \\
Nitroguaiacol & $(5.7 \pm 2.5)$ & $(6.7 \pm 4.7)$ & $(3.6 \pm 1.6)$ \\
$1: 1$ Pahokee Peat/Levoglucosan & $(2.0 \pm 0.9)$ & $(6.8 \pm 4.2)$ & $(1.1 \pm 0.2)$ \\
$1: 1$ Pahokee Peat/Nitroguaiacol & $(2.7 \pm 1.2)$ & $(23.8 \pm 13.0)$ & $(2.8 \pm 0.8)$ \\
$1: 10$ Pahokee Peat/Nitroguaiacol & $(4.3 \pm 1.8)$ & $(17.2 \pm 11.5)$ & $(2.3 \pm 0.6)$ \\
$1: 100$ Pahokee Peat/Nitroguaiacol & $(2.5 \pm 0.8)$ & $(3.8 \pm 0.9)$ & $(3.8 \pm 1.2)$ \\
$10: 1:$ 3 Levoglucosan/ & $(8.5 \pm 4.5)$ & $(27.7 \pm 8.7)$ & $(1.4 \pm 0.5)$ \\
Pahokee Peat/Nitroguaiacol & & & \\
\hline
\end{tabular}

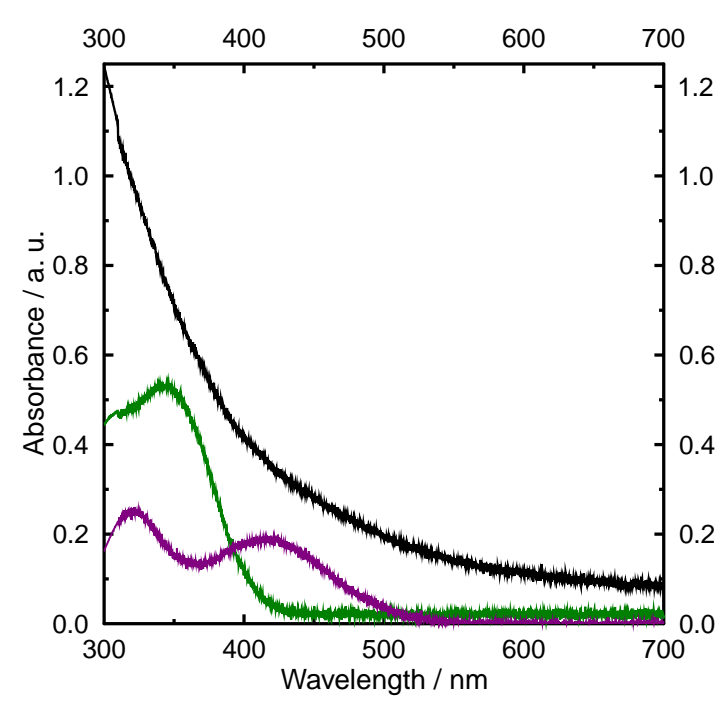

Fig. 5. Comparison of relative absorbances as a function of wavelength. Aqueous Pahokee peat, centrifuged to remove particulate matter, is shown in black, and 5-nitroguaiacol in a $0.01 \mathrm{M} \mathrm{HCl}$ solution $(\mathrm{pH}=2)$ and a $0.01 \mathrm{M} \mathrm{NaOH}$ solution $(\mathrm{pH}=12)$ are shown in green and purple, respectively.

$(\mathrm{pH}=2)$ and at wavelengths smaller than $500 \mathrm{~nm}$ under basic conditions $(\mathrm{pH}=12)$. The sparsity of photon flux density of our VIS irradiation source at wavelengths between 400 and $550 \mathrm{~nm}$ may explain the insignificant enhancement in $\gamma$ for pure NG when exposed to VIS irradiation. The addition of the PP photosensitiser to LEV yields a higher mean $\gamma$ under VIS irradiation; however, the uncertainty is too large to corroborate an enhancement. Since uptake of $\mathrm{O}_{3}$ by pure PP is enhanced under VIS irradiation, $\gamma$ of the PP/LEV substrate should be enhanced due to the presence of PP. However, PP may be buried within LEV, thus hindering its phosensitising properties and making it inaccessible for reaction with $\mathrm{O}_{3}$. Different levels of PP burial may explain the resulting range in uncertainty. The addition of PP to NG yields enhanced uptake of $\mathrm{O}_{3}$ by a factor of 3.6, as given in Table 2. This

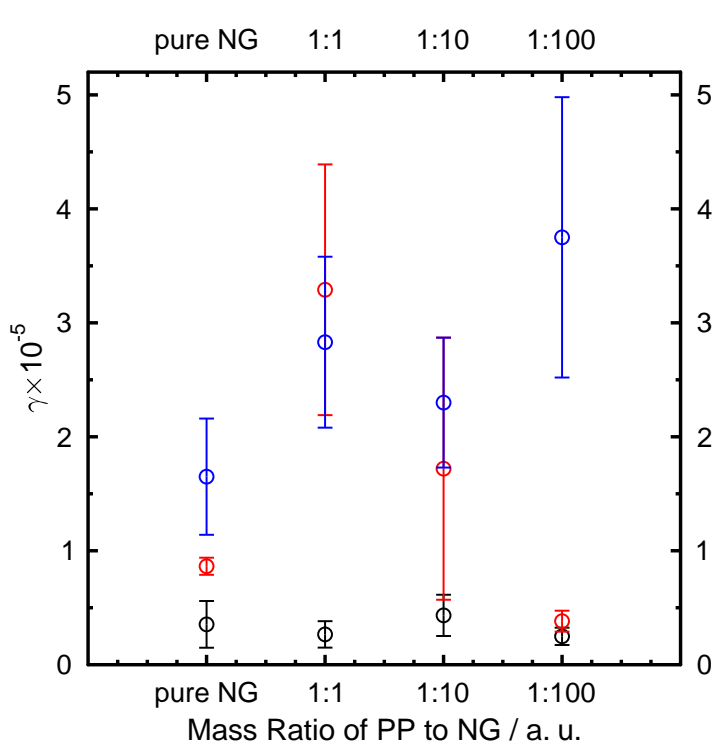

Fig. 6. Steady-state reactive uptake coefficients, $\gamma$, as a function of mass ratio of Pahokee peat to 5-nitroguaiacol. Black, red, and blue open circles denote dark, VIS, and UV irradiated uptake experiments, respectively. Errors bars denote $1 \sigma$ of the mean $\gamma$.

supports the notion that the substituted phenolic structure of NG can efficiently absorb excitation energy from PP due to a lower redox potential than PP, and subsequently adsorb or react with $\mathrm{O}_{3}$. Decreasing the ratio of PP to NG causes a decrease in $\gamma$, as shown in Fig. 6. This is most likely due to the increasing dominance of NG, which does not efficiently absorb VIS radiation, and because there is less PP available to transfer energy to NG. The 10:1:3 LEV/PP/NG substrate yields an enhanced $\gamma$ under VIS irradiation that lies between the $\gamma$ derived from the $1: 1$ and $1: 10 \mathrm{PP} / \mathrm{NG}$ substrates.

\subsubsection{UV irradiation experiments}

Steady-state $\gamma$ values measured in the presence of UV irradiation were conducted under dry conditions, with 


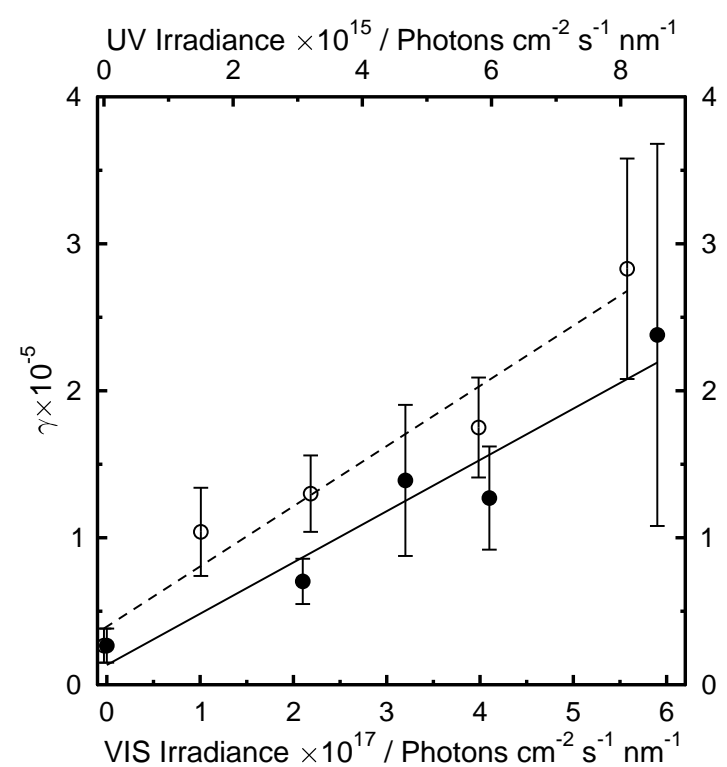

Fig. 7. Steady-state reactive uptake coefficients, $\gamma$, of the $1: 1$ by mass PP/NG substrate with $\mathrm{O}_{3}$ as a function of photon flux shown as closed and open circles for exposure to VIS and UV irradiation, respectively. The open circles refer to the top x-axis. Errors bars denote $1 \sigma$ of the mean $\gamma$. Solid and dashed lines denote linear fits of the VIS and UV irradiated uptake data, respectively.

atmospherically relevant $\mathrm{O}_{2}$, and with surface temperatures of $20^{\circ} \mathrm{C}$. Similar to the VIS irradiation experiments, most of the experiments were performed using the pullback method, aside from a few experiments using the $1: 1 \mathrm{PP} / \mathrm{NG}$ substrate that were performed using the stepwise method. These two methods also yielded similar $\gamma$ values, within the experimental error. The PP substrate yields a $\gamma$ that is a factor of $\sim 5$ higher when exposed to UV radiation compared to dark values. As mentioned previously, this is slightly smaller than $\gamma$ reported by D'Anna et al. (2009), most likely because the UV irradiation applied to the organic substrate was smaller in our study. The LEV substrate does not yield enhanced uptake of $\mathrm{O}_{3}$ under UV irradiation within experimental error. However, the NG substrate yields significantly enhanced $\gamma$ values when exposed to UV irradiation. This is most likely because NG absorbs efficiently at these wavelengths, regardless of $\mathrm{pH}$, as shown in Fig. 5. Previous studies have also shown that nitrated phenols absorb efficiently at wavelengths smaller than $450 \mathrm{~nm}$ (Jacobson, 1999). The addition of PP to the LEV substrate yields a slight enhancement in $\gamma$ compared to dark values, but this enhancement is most likely due to PP, and not to an energy transfer between PP and LEV. The addition of PP to NG also yields enhanced $\gamma$ values compared to $\gamma$ determined in the dark. However, there is little difference in $\gamma$ when varying the mass ratios of PP to NG, as shown in Fig. 6. This is most likely due to the efficient absorption of UV radiation by NG. The 10:1:3 LEV/PP/NG substrate yields a slightly enhanced $\gamma$ that is similar to that of the $1: 1$ PP/LEV substrate.

\subsection{Effect of photon flux on $\mathrm{O}_{3}$ uptake}

We measured $\gamma$ of the $1: 1 \mathrm{PP} / \mathrm{NG}$ substrate with $\mathrm{O}_{3}$ as a function of irradiation intensity. These experiments were conducted in dry conditions with atmospherically relevant $\mathrm{O}_{2}$, and $\left[\mathrm{O}_{3}\right]=(4.60 \pm 0.53) \times 10^{11}$ molecule $\mathrm{cm}^{-3}$. We observe a linear dependence of $\gamma$ on photon flux using both VIS and UV irradiation, as shown in Fig. 7. $\gamma$ as a function of VIS photon flux can be described by a linear relationship in the form of $\gamma=3.5 \times 10^{-21} . \Phi+1.3 \times 10^{-6}$, where $\Phi$ is the photon flux in photons $\mathrm{cm}^{-2} \mathrm{~s}^{-1}$. Similarly, $\gamma$ as a function of UV photon flux can be expressed as $\gamma=2.8 \times 10^{-21} \cdot \Phi+3.8 \times 10^{-6}$.

\subsection{Effect of $\mathrm{O}_{3}$ concentration on $\mathrm{O}_{3}$ uptake}

Most of the experiments conducted in this study yielded an initial fast uptake of $\mathrm{O}_{3}$ followed by a slower recovery of the $\mathrm{O}_{3}$ signal, possibly indicating adsorption of gas molecules to the organic substrate. Hence, $\gamma$ as a function of $\mathrm{O}_{3}$ concentration is determined. For total VIS and UV irradiation fluxes of $5.9 \times 10^{17}$ and $8.1 \times 10^{15}$ photons $\mathrm{cm}^{-2} \mathrm{~s}^{-1}$, respectively, $\gamma$ of the $1: 1 \mathrm{PP} / \mathrm{NG}$ substrate with $\mathrm{O}_{3}$ concentrations ranging from $1.74 \times 10^{11}$ to $1.89 \times 10^{12}$ molecule $\mathrm{cm}^{-3}$ have been determined. The inverse dependency of $\gamma$ on $\mathrm{O}_{3}$ concentration is presented in Fig. 8. Figure 8a shows that under VIS irradiation $\gamma$ increases by a factor of $\sim 6$ when $\left[\mathrm{O}_{3}\right]$ decreases from 71.3 to $7.5 \mathrm{ppb}$. A similar dependency of $\gamma$ on $\left[\mathrm{O}_{3}\right]$ is observed when the substrate is irradiated by UV as shown in Fig. 8b. $\gamma$ increases by a factor of $\sim 3$ when $\left[\mathrm{O}_{3}\right]$ decreases from 73.7 to $7.7 \mathrm{ppb}$. These trends in $\gamma$ with $\left[\mathrm{O}_{3}\right]$ are similar to the decreases in $\gamma$ observed by D'Anna et al. (2009) using only PP as a substrate and UV-A irradiation.

A decrease in uptake when the concentration of the gas phase oxidant increases is commonly interpreted as a Langmuir-Hinshelwood type uptake mechanism, where oxidant adsorption is followed by reaction on the surface and potentially in the bulk (Pöschl et al., 2001; Ammann et al., 2003; Shiraiwa et al., 2012). The data shown in Fig. 8 are represented by a Langmuir-type isotherm of the form (Ammann et al., 2003)

$$
\gamma=\frac{4 k_{\mathrm{s}}[\mathrm{Org}]_{\mathrm{s}} K_{\mathrm{O}_{3}}}{c \sigma_{\mathrm{O}_{3}}\left(1+K_{\mathrm{O}_{3}}\left[\mathrm{O}_{3}\right]_{\mathrm{g}}\right)},
$$

where $k_{\mathrm{S}}$ is the second-order rate constant, $[\mathrm{Org}]_{\mathrm{s}}$ is the surface concentration of the organic species, $K_{\mathrm{O}_{3}}$ is the $\mathrm{O}_{3}$ adsorption/desorption equilibrium constant, and $\sigma_{\mathrm{O}_{3}}$ is the surface area occupied by one adsorbed molecule of $\mathrm{O}_{3}$. The experimental data under VIS irradiation are represented by a fit of Eq. (3), as shown in Fig. 8a. Assuming $[\mathrm{Org}]_{\mathrm{s}}=5.9 \times$ $10^{14}$ molecule $\mathrm{cm}^{-2}$ and $\sigma_{\mathrm{O}_{3}}=1.7 \times 10^{-15} \mathrm{~cm}^{2}$ molecule ${ }^{-1}$ (Pöschl et al., 2001; Shiraiwa et al., 2009; Springmann et al., 


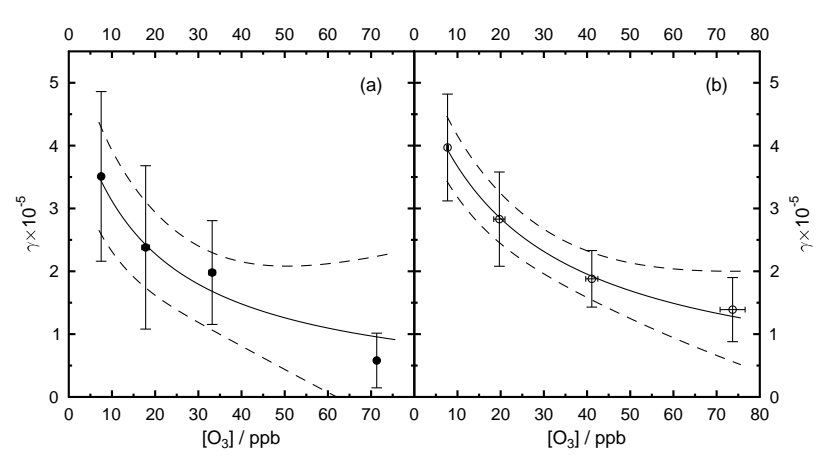

Fig. 8. Steady-state reactive uptake coefficients, $\gamma$, of $1: 1$ by mass PP/NG substrate with $\mathrm{O}_{3}$ as a function of $\mathrm{O}_{3}$ concentration under VIS (a) and UV (b) irradiation. Errors bars denote $1 \sigma$ of the mean $\gamma$. The solid lines represent a Langmuir-Hinshelwood reactive uptake mechanism fit to the data, and dashed lines indicate corresponding $95 \%$ confidence bands.

2009; Kaiser et al., 2011), the determined fit parameters are $k_{\mathrm{s}}=(5.5 \pm 2.7) \times 10^{-19} \mathrm{~cm}^{2} \mathrm{~s}^{-1}$ molecule ${ }^{-1}$ and $K_{\mathrm{O}_{3}}=$ $(2.3 \pm 2.0) \times 10^{-12} \mathrm{~cm}^{3}$ molecule ${ }^{-1}$. Derived $k_{\mathrm{s}}$ is similar in magnitude to $k_{\mathrm{s}}$ derived in previous studies for $\mathrm{O}_{3}$ uptake by solid polycyclic aromatic hydrocarbons (PAHs) (Pöschl et al., 2001; Shiraiwa et al., 2009). Derived $K_{\mathrm{O}_{3}}$ is larger than typical values reported in the literature (Pöschl et al., 2001; Kwamena et al., 2007; Shiraiwa et al., 2009). Pöschl et al. (2001) report $K_{\mathrm{O}_{3}}=(2.8 \pm 0.2) \times 10^{-13} \mathrm{~cm}^{3}$ molecule $^{-1}$ for benzo[a]pyrene (BaP)-coated soot with $\mathrm{O}_{3}$; however, most $K_{\mathrm{O}_{3}}$ values for uptake of $\mathrm{O}_{3}$ by solid aerosol are on the order of $10^{-14}-10^{-16} \mathrm{~cm}^{3}$ molecule ${ }^{-1}$ (Shiraiwa et al., 2009). Kwamena et al. (2007) suggest that $\mathrm{O}_{3}$ preferentially partitions to nonpolar surfaces. This could explain the large $K_{\mathrm{O}_{3}}$ value observed by Pöschl et al. (2001) since soot surfaces are highly nonpolar. However, both PP and NG are polar substances, so this cannot explain the high $K_{\mathrm{O}_{3}}$ determined in our study. Kwamena et al. (2007) also suggest that a higher value of $K_{\mathrm{O}_{3}}$ may be due to a stronger binding interaction of the initial $\mathrm{O}_{3} /$ substrate complex. In this case, the excitation of the PP/NG substrate upon irradiation may cause $\mathrm{O}_{3}$ to bind more strongly to the surface, yielding a higher value for $K_{\mathrm{O}_{3}}$.

The experimental data under UV irradiation are represented by a fit of Eq. (3), as shown in Fig. 8b. Using the same values for $[\mathrm{Org}]_{\mathrm{s}}$ and $\sigma_{\mathrm{O}_{3}}$, the determined fit parameters are $k_{\mathrm{s}}=(8.1 \pm 2.0) \times 10^{-19} \mathrm{~cm}^{2} \mathrm{~s}^{-1}$ molecule ${ }^{-1}$ and $K_{\mathrm{O}_{3}}=$ $(1.7 \pm 0.7) \times 10^{-12} \mathrm{~cm}^{3}$ molecule ${ }^{-1}$. Similar to the experimental data under VIS irradiation, derived $k_{\mathrm{s}}$ is similar in magnitude to $k_{\mathrm{s}}$ derived in previous studies (Pöschl et al., 2001; Shiraiwa et al., 2009). Derived $K_{\mathrm{O}_{3}}$ is similar to that obtained for the VIS uptake experiments, indicating that also for the UV case the presence of irradiation may enhance the binding of $\mathrm{O}_{3}$ to the organic substrate.
An alternative explanation for the saturation behaviour of $\gamma$ with increasing $\mathrm{O}_{3}$ concentration could be the deactivation of the photosensitiser through reaction with photo-oxidants formed simultaneously during irradiation of the organic substrate (Stemmler et al., 2006, 2007; Bartels-Rausch et al., 2010). These photo-oxidants may act to quench the photosensitiser, making it unavailable for reaction with $\mathrm{O}_{3}$ at higher $\mathrm{O}_{3}$ concentrations similar to the observed saturation of $\mathrm{HONO}$ formation at high $\mathrm{NO}_{2}$ concentrations (Stemmler et al., 2006). This explanation for $\gamma$ saturation with increasing oxidant concentrations is motivated by the observation that $\gamma$ increases nonlinearly with increasing photon flux, supporting the theory that photo-oxidants formed on the surface may deactivate the photosensitiser. However, we observe a linear increase in $\gamma$ with increasing photon flux. This observation may support the concept that adsorption of $\mathrm{O}_{3}$ at the organic substrate surface may be the dominant cause of the saturation behaviour of $\gamma$.

\section{Atmospheric implications}

This study shows that NG in the presence of PP acting as a photosensitiser exhibits enhanced $\mathrm{O}_{3}$ uptake under VIS and UV irradiation with potential consequences for atmospheric chemistry. $\mathrm{O}_{3}$ uptake by LEV with and without PP acting as a photosensitiser is not enhanced compared to pure LEV under VIS and UV irradiation.

An interesting component of this study is the importance of UV radiation compared to VIS irradiation on the photosensitised heterogeneous oxidation kinetics. For example, the total UV photon flux is almost 2 orders of magnitude smaller than for the VIS regime, but the $\gamma$ values are about $15 \%$ larger under UV irradiation. This indicates that photoenhanced chemical ageing will be important under UV-A irradiation, even though the UV-A photon flux from the sun is much less than that of the VIS photon flux. Furthermore, since UV-A irradiation increases with height, it can be expected that organic particles containing photosensitising compounds, such as BBA, in the upper troposphere or lower stratosphere (UT/LS) can experience significant photosensitised chemical ageing during transport.

As shown above, $\gamma$ for the $1: 1 \mathrm{PP} / \mathrm{NG}$ substrate can be expressed as a function of photon flux by a linear relationship. This relationship can be exploited to determine $\gamma$ under VIS irradiation from the sun as $\gamma=4.8 \times 10^{-6}$ for an irradiance of $1.0 \times 10^{17}$ photons $\mathrm{cm}^{-2} \mathrm{~s}^{-1}$ in the $400-700$ region. As mentioned previously, the VIS irradiation source emits predominantly in the "red" wavelength range compared to the wavelengths emitted by the sun. As a consequence, $\gamma$ determined here may be considered a lower limit since under atmospheric conditions light is received more uniformly as a function of wavelength, as shown in Fig. 2. $\gamma$ under UV irradiation from the sun as determined from the above linear relationship is $1.97 \times 10^{-5}$ for an irradiance of 
$5.6 \times 10^{15}$ photons $\mathrm{cm}^{-2} \mathrm{~s}^{-1}(300-400 \mathrm{~nm})$. However, the UV irradiation source used in this study peaks between 362 and $372 \mathrm{~nm}$, whereas the sun emits irradiation continually from 300 to $400 \mathrm{~nm}$. Thus, also in this case, the derived $\gamma$ may represent a lower limit.

Previous studies have shown that the number of gas molecules lost to the organic substrate will be proportional to the product of $\gamma$ and the concentration of the oxidant species (Moise and Rudich, 2001; Knopf et al., 2006; Gross and Bertram, 2008; Knopf et al., 2011). Therefore, we utilise the $\gamma$ values determined in this study to report oxidative power, i.e. $\gamma \cdot\left[\mathrm{O}_{3}\right]$. This parameter allows one to evaluate the importance of different atmospheric oxidants in terms of gas phase loss, effect on atmospheric composition and chemistry, and oxidation potential of the condensed phase species. Shown in Fig. 9a is the oxidative power for the 1:1 PP/NG substrate as a function of $\mathrm{O}_{3}$ concentration under VIS and UV irradiation. $\gamma$ values used for calculation of the oxidative power are determined from the LH relationships given in Fig. 8a, b, and at irradiation of $5.9 \times 10^{17}$ and $8.1 \times 10^{15}$ photons $\mathrm{cm}^{-2} \mathrm{~s}^{-1}$ for VIS and UV, respectively. For atmospherically relevant levels of $\mathrm{O}_{3}$ between $1 \mathrm{ppb}$ and $120 \mathrm{ppb}$, the oxidative power is greater than $1 \times 10^{6}$ molecule $\mathrm{cm}^{-3}$. The determined $\gamma \cdot\left[\mathrm{O}_{3}\right]$ are about an order of magnitude greater than those of solid PAH surfaces reacting with $100 \mathrm{ppb} \mathrm{O}_{3}$ (Gross and Bertram, 2008). At $100 \mathrm{ppb}, \gamma \cdot\left[\mathrm{O}_{3}\right]$ is $1.8 \times 10^{7}$ molecule $\mathrm{cm}^{-3}$ under VIS irradiation and $2.5 \times 10^{7}$ molecule $\mathrm{cm}^{-3}$ under UV irradiation. $\gamma \cdot\left[\mathrm{O}_{3}\right]$ can be determined for any other $\mathrm{O}_{3}$ concentration using the fit parameters derived from the above Langmuir isotherms to calculate $\gamma$. Although the uptake of $\mathrm{O}_{3}$ may be slow compared to the uptake of the $\mathrm{OH}$ radical, the abundance of $\mathrm{O}_{3}$ compared to $\mathrm{OH}$ yields $\gamma \cdot\left[\mathrm{O}_{3}\right]$ values that are about twice that of $\gamma \cdot[\mathrm{OH}]$ (Yokelson et al., 2009; Slade and Knopf, 2013).

$\gamma \cdot\left[\mathrm{O}_{3}\right]$ is also determined as a function of photon flux, as shown in Fig. 9b. At a fixed $\left[\mathrm{O}_{3}\right]$ of $\sim 20 \mathrm{ppb}, \gamma \cdot\left[\mathrm{O}_{3}\right]$ is greater than $1 \times 10^{6}$ molecule $\mathrm{cm}^{-3}$ for all given photon fluxes. $\gamma \cdot\left[\mathrm{O}_{3}\right]$ for the average total VIS and UV irradiances from the sun are $1.2 \times 10^{7}$ and $4.9 \times 10^{7}$ molecule $^{-3}$, respectively.

We can use measured $\gamma$ to estimate the particle lifetime, $\tau$, of NG, which is suggested to serve as a molecular marker for BBA particles. We assume NG is in the presence of PP acting as a photosensitiser; however we do not account for degradation of PP. Particle lifetime is calculated following Robinson et al. (2006a):

$\tau=\frac{4}{3} r \frac{\rho N_{\mathrm{a}}}{\gamma c\left[\mathrm{O}_{3}\right] M}$,

where $r$ is the radius of the particle, $\rho$ is the particle density $\left(1.367 \mathrm{~g} \mathrm{~cm}^{-1}\right.$ for NG, Dinar et al., 2006), and $M$ is the molecular weight of the organic species of interest $(M=$ $169.13 \mathrm{~g} \mathrm{~mol}^{-1}$ for NG). Here we assume a $0.4 \mu \mathrm{m}$ diameter NG particle.

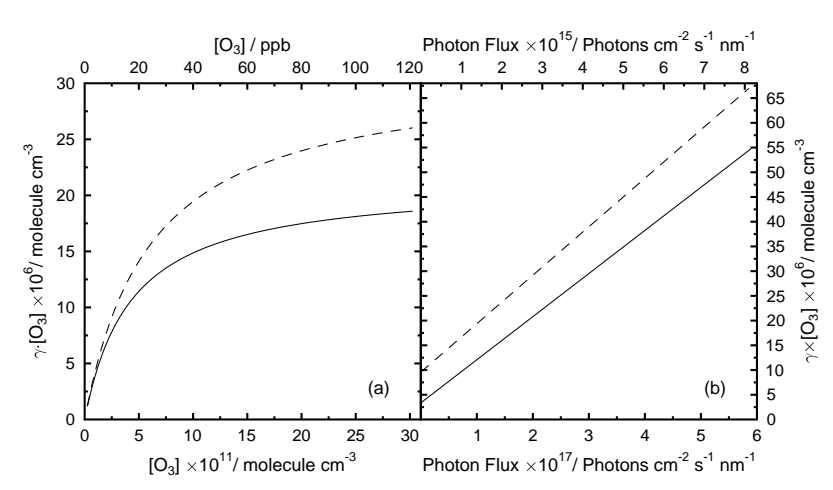

Fig. 9. Oxidative power, $\gamma \cdot\left[\mathrm{O}_{3}\right]$, as a function of $\left[\mathrm{O}_{3}\right]$ (a) and photon flux (b) for the $1: 1$ by mass PP/NG substrate. Solid and dashed lines represent oxidative power under VIS and UV irradiation, respectively. Dashed line in (b) refers to top X-axis.

Shown in Fig. 10a is the lifetime of a NG particle as a function of $\left[\mathrm{O}_{3}\right]$ under VIS and UV irradiation. $\gamma$ values used in calculating the lifetime are determined from the LH relationships given in Fig. 8a, b, and at irradiation of $5.9 \times 10^{17}$ and $8.1 \times 10^{15}$ photons $\mathrm{cm}^{-2} \mathrm{~s}^{-1}$ for VIS and UV, respectively. For atmospherically relevant levels of $\mathrm{O}_{3}$ between $20 \mathrm{ppb}$ and $120 \mathrm{ppb}$, particle lifetimes range from 39 to 88 daylight hours. The lifetime can be determined for any $\left[\mathrm{O}_{3}\right]$ using the fit parameters derived from the above Langmuirtype isotherms to calculate $\gamma$. Figure $10 \mathrm{~b}$ shows the particle lifetime as a function of photon flux, with $\left[\mathrm{O}_{3}\right] \sim 20 \mathrm{ppb}$. The lifetimes range from 91 to 1490 daylight hours under VIS irradiation and 75 to 520 daylight hours under UV irradiation. These results show that under typical atmospheric transport times of about 1 week, the biomolecular marker NG can be significantly oxidised in the presence of a photosensitiser and VIS or UV irradiation. As discussed above, due to the spectral characteristics of the applied irradiation sources and absorbance features of NG, derived $\gamma$ values may represent lower limits, making these lifetime estimates upper limits. However, shielding effects due to the presence of nonreactive compounds at the surface of the particle have not been accounted for and may extend particle lifetime.

Smoke and other absorbing aerosol have been observed in the UT/LS (Jost et al., 2004; Fromm et al., 2010). A study by Fromm et al. (2010) proposes that injection of BB emissions through pyrocumulonimbus (pyroCb) clouds could be an important source of stratospheric aerosol particles. The aerosol particles injected by pyroCb are transported throughout the UT/LS and can subsequently undergo chemical ageing. Due to the sufficiently high altitude of pyroCb smoke, the aerosol particles are exposed to much higher levels of UV-A irradiation. According to Piazena (1996), UV-A irradiation at $10 \mathrm{~km}$ height can be $70-150 \%$ higher than at ground level depending on solar elevation. Coupled with the high levels of $\mathrm{O}_{3}$ found in aged BB plumes (Delany et al., 1985; Andreae et al., 1988; Crutzen and Andreae, 1990; Ziemke et al., 2009; 


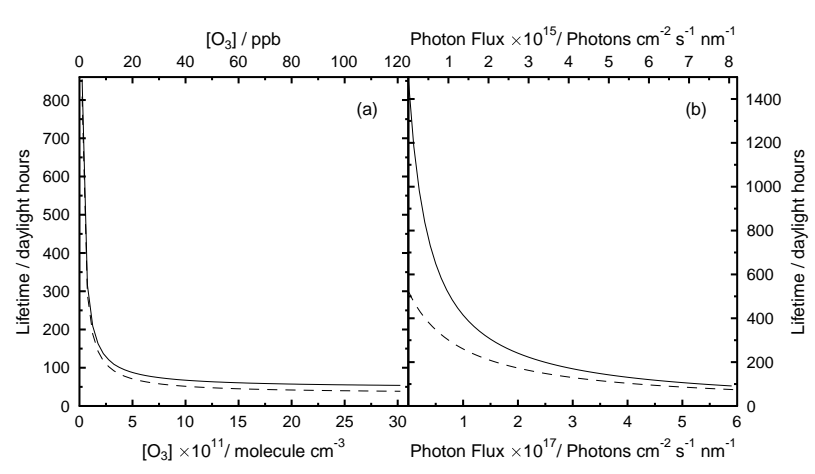

Fig. 10. Atmospheric lifetime, $\tau$, of a $0.4 \mu \mathrm{m}$ 5-nitroguaiacol particle as a function of $\left[\mathrm{O}_{3}\right]$ (a) and photon flux (b) determined using $\gamma$ of the $1: 1$ by mass PP/NG substrate. Solid and dashed lines represent derived lifetime under VIS and UV irradiation, respectively. Dashed line in (b) refers to top x-axis.

Konovalov et al., 2011; Dupont et al., 2012; Martins et al., 2012; Akagi et al., 2013), uptake of $\mathrm{O}_{3}$ by BBA compounds can be significant. For example, using a solar elevation angle of $\sim 70^{\circ} \mathrm{C}$, which roughly corresponds to a summer afternoon in the midwestern US, UV-A irradiation at $10 \mathrm{~km}$ height is $9.52 \times 10^{15}$ photons $\mathrm{cm}^{-2} \mathrm{~s}^{-1}$. This corresponds to a $\gamma$ value of $3.05 \times 10^{-5}$ using the linear relationship of $\gamma$ with photon flux. This corresponds to a NG particle lifetime of about 40 daylight hours at $100 \mathrm{ppb}$.

\section{Conclusions}

A novel irradiated rectangular channel flow reactor coupled to CIMS has been developed and successfully validated allowing for the investigation of the effect of irradiation on the heterogeneous oxidation kinetics of organic compounds typical of biomass burning aerosol at low pressures and applying atmospherically relevant oxidant concentrations. The effect of VIS and UV irradiation on the reactive uptake coefficients of levoglucosan and 5-nitroguaiacol with $\mathrm{O}_{3}$ has been determined with and without the presence of Pahokee peat acting as a photosensitiser. The reactive uptake of $\mathrm{O}_{3}$ by a $10: 1: 3$ by mass mixture of levoglucosan, Pahokee peat, and 5-nitroguaiacol in dark, VIS, and UV irradiation conditions was also determined. The uptake of $\mathrm{O}_{3}$ by LEV without PP yields no enhancement when exposed to VIS or UV irradiation, while the uptake of $\mathrm{O}_{3}$ by NG without PP is enhanced by a factor of $\sim 6$ when exposed to UV irradiation, yielding $\gamma=3.6 \times 10^{-5} \cdot \gamma$ of the $1: 1$ by mass PP/LEV substrate is not enhanced when exposed to either VIS or UV irradiation, within experimental error. However, $\gamma$ of the $1: 1$ by mass PP/NG substrate is enhanced by about an order of magnitude under both VIS and UV irradiation, yielding values of $2.4 \times 10^{-5}$ and $2.8 \times 10^{-5}$, respectively. $\gamma$ of the PP/NG substrates decreases (remains constant) as the mass ratio of PP to NG decreases under VIS (UV) irradiation. $\gamma$ of the $10: 1: 3$
LEV/PP/NG substrate is also enhanced under both VIS and UV irradiation, yielding values of $2.8 \times 10^{-5}$ and $1.4 \times 10^{-5}$, respectively.

We observed that the reactive uptake coefficient for constant $\mathrm{O}_{3}$ concentration by a $1: 1 \mathrm{PP} / \mathrm{NG}$ substrate increases linearly as a function of VIS and UV irradiation, allowing for extrapolation of $\gamma$ to atmospherically relevant photon fluxes. Determined $\gamma$ of the $1: 1 \mathrm{PP} / \mathrm{NG}$ substrate under constant VIS and UV irradiation decreases as $\mathrm{O}_{3}$ concentration increases. This behaviour is interpreted as a LangmuirHinshelwood type uptake mechanism and the data is represented by a Langmuir-type isotherm. From the experimental data under VIS irradiation, the second-order rate constant $k_{\mathrm{s}}=(5.5 \pm 2.7) \times 10^{-19} \mathrm{~cm}^{2} \mathrm{~s}^{-1}$ molecule ${ }^{-1}$ and the $\mathrm{O}_{3}$ adsorption/desorption equilibrium constant $K_{\mathrm{O}_{3}}=(2.3 \pm 2.0) \times$ $10^{-12} \mathrm{~cm}^{3}$ molecule ${ }^{-1} . \mathrm{O}_{3}$ uptake by the $1: 1 \mathrm{PP} / \mathrm{NG}$ substrate under UV irradiation yields the analogous parameters $k_{\mathrm{s}}=(8.1 \pm 2.0) \times 10^{-19} \mathrm{~cm}^{2} \mathrm{~s}^{-1}$ molecule ${ }^{-1}$ and $K_{\mathrm{O}_{3}}=$ $(1.7 \pm 0.7) \times 10^{-12} \mathrm{~cm}^{3}$ molecule $^{-1}$.

The experimental data allow for derivation of the oxidative power as a function of the sun's photon flux and $\mathrm{O}_{3}$ concentration, indicating that, for atmospherically relevant conditions, these BBA surrogate species can be efficiently oxidised with subsequent implications for source apportionment studies. Estimated 5-nitroguaiacol particle lifetimes indicate that these BBA biomarkers can undergo significant degradation during typical atmospheric transport times of up to one week. Since the sun emits radiation with smaller wavelengths than applied irradiation sources, derived $\gamma$ and lifetimes may represent lower and upper limits, respectively. In addition, since the VIS and UV flux can increase significantly with altitude, photosensitive chemical ageing may be even more efficient in the upper troposphere/lower stratosphere.

Acknowledgements. The authors are grateful to J. Slechta for technical support. We would also like to thank A. Sedlacek for use of the fibre optic spectrometer, and J. Marecek for performing the absorbance measurements. This work was supported by the National Science Foundation, Grant AGS-0846255.

Edited by: M. Ammann

\section{References}

Akagi, S. K., Yokelson, R. J., Burling, I. R., Meinardi, S., Simpson, I., Blake, D. R., McMeeking, G. R., Sullivan, A., Lee, T., Kreidenweis, S., Urbanski, S., Reardon, J., Griffith, D. W. T., Johnson, T. J., and Weise, D. R.: Measurements of reactive trace gases and variable $\mathrm{O}_{3}$ formation rates in some South Carolina biomass burning plumes, Atmos. Chem. Phys., 13, 1141-1165, doi:10.5194/acp-13-1141-2013, 2013.

Ammann, M., Pöschl, U., and Rudich, Y.: Effects of reversible adsorption and Langmuir-Hinshelwood surface reactions on gas uptake by atmospheric particles, Phys. Chem. Chem. Phys., 5, 351-356, doi:10.1039/B208708A, 2003. 
Anastasio, C., Faust, B. C., and Rao, C. J.: Aromatic carbonyl compounds as aqueous-phase photochemical sources of hydrogen peroxide in acidic sulfate aerosols, fogs, and clouds, 1. Non-phenolic methoxybenzaldehydes and methoxyacetophenones with reductants (phenols), Environ. Sci. Technol., 31, 218232, doi:10.1021/es960359g, 1997.

Andreae, M. O.: A new look at aging aerosols, Science, 326, 14931494, doi:10.1126/science.1183158, 2009.

Andreae, M. O., Browell, E. V., Garstang, M., Gregory, G. L., Harriss, R. C., Hill, G. F., Jacob, D. J., Pereira, M. C., Sachse, G. W., Setzer, A. W., Dias, P. L. S., Talbot, R. W., Torres, A. L., and Wofsy, S. C.: Biomass-burning emissions and associated haze layers over amazonia, J. Geophys. Res., 93, 1509-1527, doi:10.1029/JD093iD02p01509, 1988.

Atkinson, R. and Carter, W. P. L.: Kinetics and mechanisms of the gas-phase reactions of ozone with organic compounds under atmospheric conditions, Chem. Rev., 84, 437-470, doi:10.1021/cr00063a002, 1984.

Baduel, C., Monge, M. E., Voisin, D., Jaffrezo, J.-L., George, C., Haddad, I. E., Marchand, N., and D'Anna, B.: Oxidation of atmospheric humic like substances by ozone: a kinetic and structural analysis approach, Environ. Sci. Technol., 45, 5238-5244, doi:10.1021/es200587z, 2011.

Bartels-Rausch, T., Brigante, M., Elshorbany, Y. F., Ammann, M., D’Anna, B., George, C., Stemmler, K., Ndour, M., and Kleffmann, J.: Humic acid in ice: Photo-enhanced conversion of nitrogen dioxide into nitrous acid, Atmos. Env., 44, 5443-5450, doi:10.1016/j.atmosenv.2009.12.025, http://www.sciencedirect. com/science/article/pii/S1352231009010590, 2010.

Brigante, M., Cazoir, D., D’Anna, B., George, C., and Donaldson, D. J.: Photoenhanced uptake of $\mathrm{NO}_{2}$ by pyrene solid films, J. Phys. Chem. A, 112, 9503-9508, doi:10.1021/jp802324g, 2008.

Canonica, S., Jans, U., Stemmler, K., and Hoigné, J.: Transformation kinetics of phenols in water: photosensitization by dissolved natural organic material and aromatic ketones, Environ. Sci. Technol., 29, 1822-1831, doi:10.1021/es00007a020, 1995.

Canonica, S., Hellrung, B., and Wirz, J.: Oxidation of phenols by triplet aromatic ketones in aqueous solution, J. Phys. Chem. A, 104, 1226-1232, doi:10.1021/jp9930550, 2000.

Crutzen, P. J. and Andreae, M. O.: Biomass burning in the tropics - impact on atmospheric chemistry and biogeochemical cycles, Science, 250, 1669-1678, doi:10.1126/science.250.4988.1669, 1990.

Crutzen, P. J., Heidt, L. E., Krasnec, J. P., Pollock, W. H., and Seiler, W.: Biomass burning as a source of atmospheric gases $\mathrm{CO}, \mathrm{H}_{2}, \mathrm{~N}_{2} \mathrm{O}, \mathrm{NO}, \mathrm{CH}_{3} \mathrm{Cl}$ and $\mathrm{COS}$, Nature, 282, 253-256, doi:10.1038/282253a0, 1979.

Cussler, E. L.: Diffusion: Mass Transfer in Fluid Systems, Cambridge University Press, third edn., 2010.

D’Anna, B., Jammoul, A., George, C., Stemmler, K., Fahrni, S., Amman, M., and Wisthaler, A.: Light-induced ozone depletion by humic acid films and submicron aerosol particles, J. Geophys. Res., 114, D12301, doi:10.1029/2008JD011237, 2009.

de Gouw, J. A. and Lovejoy, E. R.: Reactive uptake of ozone by liquid organic compounds, Geophys. Res. Lett., 25, 931-934, doi:10.1029/98GL00515, 1998.

Delany, A. C., Haagensen, P., Walters, S., Wartburg, A. F., and Crutzen, P. J.: Photochemically produced ozone in the emission from large-scale tropical vegetation fires, J. Geophys. Res., 90,
2425-2429, doi:10.1029/JD090iD01p02425, 1985.

Dinar, E., Mentel, T. F., and Rudich, Y.: The density of humic acids and humic like substances (HULIS) from fresh and aged wood burning and pollution aerosol particles, Atmos. Chem. Phys., 6, 5213-5224, doi:10.5194/acp-6-5213-2006, 2006.

Dupont, R., Pierce, B., Worden, J., Hair, J., Fenn, M., Hamer, P., Natarajan, M., Schaack, T., Lenzen, A., Apel, E., Dibb, J., Diskin, G., Huey, G., Weinheimer, A., Kondo, Y., and Knapp, D.: Attribution and evolution of ozone from Asian wild fires using satellite and aircraft measurements during the ARCTAS campaign, Atmos. Chem. Phys., 12, 169-188, doi:10.5194/acp-12169-2012, 2012.

Dusek, U., Frank, G. P., Massling, A., Zeromskiene, K., Inuma, Y., Schmid, O., Helas, G., Hennig, T., Wiedensohler, A., and Andreae, M. O.: Water uptake by biomass burning aerosol at suband supersaturated conditions: closure studies and implications for the role of organics, Atmos. Chem. Phys., 11, 9519-9532, doi:10.5194/acp-11-9519-2011, 2011.

Engelhart, G. J., Hennigan, C. J., Miracolo, M. A., Robinson, A. L., and Pandis, S. N.: Cloud condensation nuclei activity of fresh primary and aged biomass burning aerosol, Atmos. Chem. Phys., 12, 7285-7293, doi:10.5194/acp-12-7285-2012, 2012.

Facchini, M. C., Decesari, S., Mircea, M., Fuzzi, S., and Loglio, G.: Surface tension of atmospheric wet aerosol and cloud/fog droplets in relation to their organic carbon content and chemical composition, Atmos. Environ., 34, 4853-4857, doi:10.1016/S1352-2310(00)00237-5, 2000.

Fine, P. M., Cass, G. R., and Simoneit, B. R. T.: Chemical characterization of fine particle emissions from fireplace combustion of woods grown in the northeastern United States, Environ. Sci. Technol., 35, 2665-2675, doi:10.1021/es001466k, 2001.

Finlayson-Pitts, B. J. and Pitts, J. N.: Chemistry of the Upper and Lower Atmosphere, Academic Press, San Diego, California, 2000.

Fors, E. O., Rissler, J., Massling, A., Svenningsson, B., Andreae, M. O., Dusek, U., Frank, G. P., Hoffer, A., Bilde, M., Kiss, G., Janitsek, S., Henning, S., Facchini, M. C., Decesari, S., and Swietlicki, E.: Hygroscopic properties of Amazonian biomass burning and European background HULIS and investigation of their effects on surface tension with two models linking H-TDMA to CCNC data, Atmos. Chem. Phys., 10, 5625-5639, doi:10.5194/acp-10-5625-2010, 2010.

Fromm, M., Lindsey, D. T., Servranckx, R., Yue, G., Trickl, T., Sica, R., Doucet, P., and Godin-Beekmann, S.: The untold story of pyrocumulonimbus, B. Am. Meteorol. Soc., 91, 1193-1209, doi:10.1175/2010BAMS3004.1, 2010.

Fu, P. Q., Kawamura, K., Chen, J., Li, J., Sun, Y. L., Liu, Y., Tachibana, E., Aggarwal, S. G., Okuzawa, K., Tanimoto, H., Kanaya, Y., and Wang, Z. F.: Diurnal variations of organic molecular tracers and stable carbon isotopic composition in atmospheric aerosols over Mt. Tai in the North China Plain: an influence of biomass burning, Atmos. Chem. Phys., 12, 8359-8375, doi:10.5194/acp-12-8359-2012, 2012.

Gelencsér, A., Hoffer, A., Kiss, G., Tombacz, E., Kurdi, R., and Bencze, L.: In-situ formation of light-absorbing organic matter in cloud water, J. Atmos. Chem., 45, 25-33, doi:10.1023/A:1024060428172, 2003.

George, C., Strekowski, R. S., Kleffmann, J., Stemmler, K., and Ammann, M.: Photoenhanced uptake of gaseous $\mathrm{NO}_{2}$ on solid- 
organic compounds: a photochemical source of HONO?, Faraday Discuss., 130, 195-210, doi:10.1039/b417888m, 2005.

Gómez-Alvarez, E., Wortham, H., Strekowski, R., Zetzsch, C., and Gligorovski, S.: Atmospheric photosensitized heterogeneous and multiphase reactions: from outdoors to indoors, Environ. Sci. Technol., 46, 1955-1963, doi:10.1021/es2019675, 2012.

Gross, S. and Bertram, A. K.: Reactive uptake of $\mathrm{NO}_{3}, \mathrm{~N}_{2} \mathrm{O}_{5}$, $\mathrm{NO}_{2}, \mathrm{HNO}_{3}$, and $\mathrm{O}_{3}$ on three types of polycyclic aromatic hydrocarbon surfaces, J. Phys. Chem. A, 112, 3104-3113, doi:10.1021/jp7107544, 2008.

Gueymard, C., Myers, D., and Emery, K.: Proposed reference irradiance spectra for solar energy systems testing, Sol. Energy, 73, 443-467, doi:10.1016/S0038-092X(03)00005-7, 2002.

Hallquist, M., Wenger, J. C., Baltensperger, U., Rudich, Y., Simpson, D., Claeys, M., Dommen, J., Donahue, N. M., George, C., Goldstein, A. H., Hamilton, J. F., Herrmann, H., Hoffmann, T., Iinuma, Y., Jang, M., Jenkin, M. E., Jimenez, J. L., KiendlerScharr, A., Maenhaut, W., McFiggans, G., Mentel, Th. F., Monod, A., Prévôt, A. S. H., Seinfeld, J. H., Surratt, J. D., Szmigielski, R., and Wildt, J.: The formation, properties and impact of secondary organic aerosol: current and emerging issues, Atmos. Chem. Phys., 9, 5155-5236, doi:10.5194/acp-9-51552009, 2009.

Hanson, D. R.: Reaction of $\mathrm{ClONO}_{2}$ with $\mathrm{H}_{2} \mathrm{O}$ and $\mathrm{HCl}$ in sulfuric acid and $\mathrm{HNO}_{3} / \mathrm{H}_{2} \mathrm{SO}_{4} / \mathrm{H}_{2} \mathrm{O}$ mixtures, J. Phys. Chem. A, 102, 4794-4807, doi:10.1021/jp972767s, 1998.

Hawthorne, S. B., Miller, D. J., Barkley, R. M., and Krieger, M. S.: Identification of methoxylated phenols as candidate tracers for atmospheric wood smoke pollution, Environ. Sci. Technol., 22, 1191-1196, doi:10.1021/es00175a011, 1988.

Hawthorne, S. B., Krieger, M. S., Miller, D. J., and Mathiason, M. B.: Collection and quantitation of methoxylated phenol tracers for atmospheric pollution from residential wood stoves, Environ. Sci. Technol., 23, 470-475, doi:10.1021/es00181a013, 1989.

Hennigan, C. J., Sullivan, A. P., Collett Jr., J. L., and Robinson, A. L.: Levoglucosan stability in biomass burning particles exposed to hydroxyl radicals, Geophys. Res. Lett., 37, L09805, doi:10.1029/2010GL043088, 2010.

Hennigan, C. J., Miracolo, M. A., Engelhart, G. J., May, A. A., Presto, A. A., Lee, T., Sullivan, A. P., McMeeking, G. R., Coe, H., Wold, C. E., Hao, W.-M., Gilman, J. B., Kuster, W. C., de Gouw, J., Schichtel, B. A., J. L. Collett Jr., Kreidenweis, S. M., and Robinson, A. L.: Chemical and physical transformations of organic aerosol from the photo-oxidation of open biomass burning emissions in an environmental chamber, Atmos. Chem. Phys., 11, 7669-7686, doi:10.5194/acp-11-7669-2011, 2011.

Hobbs, P. V. and Radke, L. F.: Cloud condensation nuclei from a simulated forest fire, Science, 163, 279-280, doi:10.1126/science.163.3864.279, 1969.

Hoffmann, N.: Photochemical reactions as key steps in organic synthesis, Chem. Rev., 108, 1052-1103, doi:10.1021/cr0680336, 2008.

Jacobson, M. Z.: Isolating nitrated and aromatic aerosols and nitrated aromatic gases as sources of ultraviolet light absorption, J. Geophys. Res., 104, 3527-3542, doi:10.1029/1998JD100054, 1999.

Jammoul, A., Gligorovski, S., George, C., and D'Anna, B.: Photosensitized heterogeneous chemistry of ozone on organic films, J.
Phys. Chem. A, 112, 1268-1276, doi:10.1021/jp074348t, 2008. Jimenez, J. L., Canagaratna, M. R., Donahue, N. M., Prevot, A. S. H., Zhang, Q., Kroll, J. H., DeCarlo, P. F., Allan, J. D., Coe, H., Ng, N. L., Aiken, A. C., Docherty, K. S., Ulbrich, I. M., Grieshop, A. P., Robinson, A. L., Duplissy, J., Smith, J. D., Wilson, K. R., Lanz, V. A., Hueglin, C., Sun, Y. L., Tian, J., Laaksonen, A., Raatikainen, T., Rautiainen, J., Vaattovaara, P., Ehn, M., Kulmala, M., Tomlinson, J. M., Collins, D. R., Cubison, M. J., E., Dunlea, J., Huffman, J. A., Onasch, T. B., Alfarra, M. R., Williams, P. I., Bower, K., Kondo, Y., Schneider, J., Drewnick, F., Borrmann, S., Weimer, S., Demerjian, K., Salcedo, D., Cottrell, L., Griffin, R., Takami, A., Miyoshi, T., Hatakeyama, S., Shimono, A., Sun, J. Y., Zhang, Y. M., Dzepina, K., Kimmel, J. R., Sueper, D., Jayne, J. T., Herndon, S. C., Trimborn, A. M., Williams, L. R., Wood, E. C., Middlebrook, A. M., Kolb, C. E., Baltensperger, U., and Worsnop, D. R.: Evolution of organic aerosols in the atmosphere, Science, 326, 1525-1529, doi:10.1126/science.1180353, 2009.

Jost, H.-J., Drdla, K., Stohl, A., Pfister, L., Loewenstein, M., Lopez, J. P., Hudson, P. K., Murphy, D. M., Cziczo, D. J., Fromm, M., Bui, T. P., Dean-Day, J., Gerbig, C., Mahoney, M. J., Richard, E. C., Spichtinger, N., Pittman, J. V., Weinstock, E. M., Wilson, J. C., and Xueref, I.: In-situ observations of mid-latitude forest fire plumes deep in the stratosphere, Geophys. Res. Lett., 31, L11101, doi:10.1029/2003GL019253, 2004.

Kaiser, J. C., Riemer, N., and Knopf, D. A.: Detailed heterogeneous oxidation of soot surfaces in a particle-resolved aerosol model, Atmos. Chem. Phys., 11, 4505-4520, doi:10.5194/acp-11-45052011, 2011.

Kanakidou, M., Seinfeld, J. H., Pandis, S. N., Barnes, I., Dentener, F. J., Facchini, M. C., Van Dingenen, R., Ervens, B., Nenes, A., Nielsen, C. J., Swietlicki, E., Putaud, J. P., Balkanski, Y., Fuzzi, S., Horth, J., Moortgat, G. K., Winterhalter, R., Myhre, C. E. L., Tsigaridis, K., Vignati, E., Stephanou, E. G., and Wilson, J.: Organic aerosol and global climate modelling: a review, Atmos. Chem. Phys., 5, 1053-1123, doi:10.5194/acp-51053-2005, 2005.

Kessler, S. H., Smith, J. D., Che, D. L., Worsnop, D. R., Wilson, K. R., and Kroll, J. H.: Chemical sinks of organic aerosol: kinetics and products of the heterogeneous oxidation of erythritol and levoglucosan, Environ. Sci. Technol., 44, 7005-7010, doi:10.1021/es101465m, 2010.

Knopf, D. A., Anthony, L. M., and Bertram, A. K.: Reactive uptake of $\mathrm{O}_{3}$ by multicomponent and multiphase mixtures containing oleic acid, J. Phys. Chem. A, 109, 5579-5589, doi:10.1021/jp0512513, 2005.

Knopf, D. A., Mak, J., Gross, S., and Bertram, A. K.: Does atmospheric processing of saturated hydrocarbon surfaces by $\mathrm{NO}_{3}$ lead to volatilization?, Geophys. Res. Lett., 33, L17816, doi:10.1029/2006GL026884, 2006.

Knopf, D. A., Cosman, L. M., Mousavi, P., Mokamati, S., and Bertram, A. K.: A novel flow reactor for studying reactions on liquid surfaces coated by organic monolayers: methods, validation, and initial results, J. Phys. Chem. A, 111, 11021-11032, doi:10.1021/jp075724c, 2007.

Knopf, D. A., Forrester, S. M., and Slade, J. H.: Heterogeneous oxidation kinetics of organic biomass burning aerosol surrogates by $\mathrm{O}_{3}, \mathrm{NO}_{2}, \mathrm{~N}_{2} \mathrm{O}_{5}$, and $\mathrm{NO}_{3}$, Phys. Chem. Chem. Phys., 13, 21050-21062, doi:10.1039/C1CP22478F, 2011. 
Konovalov, I. B., Beekmann, M., Kuznetsova, I. N., Yurova, A., and Zvyagintsev, A. M.: Atmospheric impacts of the 2010 Russian wildfires: integrating modelling and measurements of an extreme air pollution episode in the Moscow region, Atmos. Chem. Phys., 11, 10031-10056, doi:10.5194/acp-11-10031-2011, 2011.

Konovalov, I. B., Beekmann, M., D’Anna, B., and George, C.: Significant light induced ozone loss on biomass burning aerosol: evidence from chemistry-transport modeling based on new laboratory studies, Geophys. Res. Lett., 39, L17807, doi:10.1029/2012GL052432, 2012.

Kwamena, N.-O. A., Staikova, M. G., Donaldson, D. J., George, I. J., and Abbatt, J. P. D.: Role of the aerosol substrate in the heterogeneous ozonation reactions of surface-bound PAHs, J. Phys. Chem. A, 111, 11050-11058, doi:10.1021/jp075300i, 2007.

Levin, E. J. T., McMeeking, G. R., Carrico, C. M., Mack, L. E., Kreidenweis, S. M., Wold, C. E., Moosmüller, H., Arnott, W. P., Hao, W. M., Collett, J. L., J., and Malm, W. C.: Biomass burning smoke aerosol properties measured during Fire Laboratory at Missoula Experiments (FLAME), J. Geophys. Res., 115, D18210, doi:10.1029/2009jd013601, 2010.

Lin, L., Lee, M. L., and Eatough, D. J.: Review of recent advances in detection of organic markers in fine particulate matter and their use for source apportionment, J. Air Waste Manage. Assoc., 60, 3-25, 2010.

Logan, J. A., Prather, M. J., Wofsy, S. C., and McElroy, M. B.: Tropospheric chemistry: a global perspective, J. Geophys. Res., 86, 7210-7254, doi:10.1029/JC086iC08p07210, 1981.

Lukács, H., Gelencsér, A., Hammer, S., Puxbaum, H., Pio, C., Legrand, M., Kasper-Giebl, A., Handler, M., Limbeck, A., Simpson, D., and Preunkert, S.: Seasonal trends and possible sources of brown carbon based on 2-yr aerosol measurements at six sites in Europe, Geophys. Res. Lett., 112, D23S18, doi:10.1029/2006jd008151, 2007.

Maria, S. F., Russell, L. M., Gilles, M. K., and Myneni, S. C. B.: Organic aerosol growth mechanisms and their climate-forcing implications, Science, 306, 1921-1924, doi:10.1126/science.1103491, 2004.

Martins, V., Miranda, A., Carvalho, A., Schaap, M., Borrego, C., and Sá, E.: Impact of forest fires on particulate matter and ozone levels during the 2003, 2004 and 2005 fire seasons in Portugal, Sci. Total Environ., 414, 53-62, doi:10.1016/j.scitotenv.2011.10.007, 2012.

Mayol-Bracero, O. L., Guyon, P., Graham, B., Roberts, G., Andreae, M. O., Decesari, S., Facchini, M. C., Fuzzi, S., and Artaxo, P.: Water-soluble organic comounds in biomass burning aerosols over Amazonia, 2. apportionment of the chemical composition and importance of the polyacidic fraction, J. Geophys. Res., 107, 8091-8106, doi:10.1029/2001JD000522, 2002.

Mikhailov, E., Vlasenko, S., Martin, S. T., Koop, T., and Pöschl, U.: Amorphous and crystalline aerosol particles interacting with water vapor: conceptual framework and experimental evidence for restructuring, phase transitions and kinetic limitations, Atmos. Chem. Phys., 9, 9491-9522, doi:10.5194/acp-9-9491-2009, 2009.

Moise, T. and Rudich, Y.: Reactive uptake of ozone by proxies for organic aerosols: surface versus bulk processes, J. Geophys. Res., 105, 14667-14676, doi:10.1029/2000JD900071, 2000.
Moise, T. and Rudich, Y.: Uptake of $\mathrm{Cl}$ and $\mathrm{Br}$ by organic surfaces perspective on organic aerosols processing by tropospheric oxidants, Geophys. Res. Lett., 28, 4083-4086, doi:10.1029/2001GL013583, 2001.

Moise, T. and Rudich, Y.: Reactive uptake of ozone by aerosol-associated unsaturated fatty acids: kinetics, mechanism, and products, J. Phys. Chem. A, 106, 6469-6476, doi:10.1021/jp025597e, 2002.

Net, S., Nieto-Gligorovski, L., Gligorovski, S., and Wortham, H.: Heterogeneous ozonation kinetics of 4-phenoxyphenol in the presence of photosensitizer, Atmos. Chem. Phys., 10, 15451554, doi:10.5194/acp-10-1545-2010, 2010.

Nissenson, P., Knox, C. J. H., Finlayson-Pitts, B. J., Phillips, L. F., and Dabdub, D.: Enhanced photolysis in aerosols: evidence for important surface effects, Phys. Chem. Chem. Phys., 8, 47004710, doi:10.1039/B609219E, 2006.

Piazena, H.: The effect of altitude upon the solar UV-B and UVA irradiance in the tropical Chilean Andes, Sol. Energy, 57, 133140, doi:10.1016/S0038-092X(96)00049-7, 1996.

Pope, C. A., Ezzati, M., and Dockery, D. W.: Fine-particulate air pollution and life expectancy in the United States, N. Engl. J. Med., 360, 376-386, doi:10.1056/NEJMsa0805646, 2009.

Pöschl, U., Letzel, T., Schauer, C., and Niessner, R.: Interaction of ozone and water vapor with spark discharge soot aerosol particles coated with benzo[a]pyrene: $\mathrm{O}_{3}$ and $\mathrm{H}_{2} \mathrm{O}$ adsorption, benzo[a]pyrene degradation, and atmospheric implications, J. Phys. Chem. A, 105, 4029-4041, doi:10.1021/jp004137n, 2001.

Ramanathan, V., Crutzen, P. J., and Rosenfeld, D.: Aerosols, climate, and the hydrological cycle, Science, 294, 2119-2124, doi:10.1126/science.1064034, 2001.

Robinson, A. L., Donahue, N. M., and Rogge, W. F.: Photochemical oxidation and changes in molecular composition of organic aerosol in the regional context, J. Geophys. Res., 111, D03302, doi:10.1029/2005JD006265, 2006a.

Robinson, A. L., Subramanian, R., Donahue, N. M., BernardoBricker, A., and Rogge, W. F.: Source apportionment of molecular markers and organic aerosol, 2. biomass smoke, Environ. Sci. Technol., 40, 7811-7819, doi:10.1021/es060782h, 2006b.

Rogge, W. F., Hildemann, L. M., Mazurek, M. A., and Cass, G. R.: Sources of fine organic aerosol, 9. pine, oak, and synthetic log combustion in residential fireplaces, Environ. Sci. Technol., 32, 13-22, doi:10.1021/es960930b, 1998.

Rudich, Y., Donahue, N. M., and Mentel, T. F.: Aging of organic aerosol: bridging the gap between laboratory and field studies, Annu. Rev. Phys. Chem., 58, 321-352, doi:10.1146/annurev.physchem.58.032806.104432, 2007.

Schmidl, C., Bauer, H., Dattler, A., Hitzenberger, R., Weissenboeck, G., Marr, I. L., and Puxbaum, H.: Chemical characterisation of particle emissions from burning leaves, Atmos. Environ., 42, 9070-9079, doi:10.1016/j.atmosenv.2008.09.010, 2008a.

Schmidl, C., Marr, L. L., Caseiro, A., Kotianova, P., Berner, A., Bauer, H., Kasper-Giebl, A., and Puxbaum, H.: Chemical characterisation of fine particle emissions from wood stove combustion of common woods growing in midEuropean Alpine regions, Atmos. Environ., 42, 126-141, doi:10.1016/j.atmosenv.2007.09.028, 2008b.

Shiraiwa, M., Garland, R. M., and Pöschl, U.: Kinetic double-layer model of aerosol surface chemistry and gas-particle interactions 
(K2-SURF): degradation of polycyclic aromatic hydrocarbons exposed to $\mathrm{O}_{3}, \mathrm{NO}_{2}, \mathrm{H}_{2} \mathrm{O}, \mathrm{OH}$ and $\mathrm{NO}_{3}$, Atmos. Chem. Phys., 9, 9571-9586, doi:10.5194/acp-9-9571-2009, 2009.

Shiraiwa, M., Pöschl, U., and Knopf, D. A.: Multiphase chemical kinetics of $\mathrm{NO}_{3}$ radicals reacting with organic aerosol components from biomass burning, Environ. Sci. Technol., 46, 66306636, doi:10.1021/es300677a, 2012.

Silvester, D. S., Wain, A. J., Aldous, L., Hardacre, C., and Compton, R. G.: Electrochemical reduction of nitrobenzene and 4-nitrophenol in the room temperature ionic liquid [C4dmim][N(Tf)2], J. Electronanal. Chem., 596, 131-140, 2006.

Simoneit, B. R. T.: Biomass burning - a review of organic tracers for smoke from incomplete combustion, Appl. Geochem., 17, 129162, doi:10.1016/S0883-2927(01)00061-0, 2002.

Slade, J. H. and Knopf, D. A.: Heterogeneous $\mathrm{OH}$ oxidation of biomass burning organic aerosol surrogate compounds: assessment of volatilisation products and the role of $\mathrm{OH}$ concentration on the reactive uptake kinetics, Phys. Chem. Chem. Phys., 15, 5898-5915, doi:10.1039/C3CP44695F, 2013.

Sosedova, Y., Rouviere, A., Bartels-Rausch, T., and Ammann, M.: UVA/Vis-induced nitrous acid formation on polyphenolic films exposed to gaseous $\mathrm{NO}_{2}$, Photochem. Photobiol. Sci., 10, 16801690, doi:10.1039/C1PP05113J, 2011.

Springmann, M., Knopf, D. A., and Riemer, N.: Detailed heterogeneous chemistry in an urban plume box model: reversible co-adsorption of $\mathrm{O}_{3}, \mathrm{NO}_{2}$, and $\mathrm{H}_{2} \mathrm{O}$ on soot coated with benzo[a]pyrene, Atmos. Chem. Phys., 9, 7461-7479, doi:10.5194/acp-9-7461-2009, 2009.

Stemmler, K., Ammann, M., Donders, C., Kleffmann, J., and George, C.: Photosensitized reduction of nitrogen dioxide on humic acid as a source of nitrous acid, Nature, 440, 195-198, doi:10.1038/nature04603, 2006.

Stemmler, K., Ndour, M., Elshorbany, Y., Kleffmann, J., D'Anna, B., George, C., Bohn, B., and Ammann, M.: Light induced conversion of nitrogen dioxide into nitrous acid on submicron humic acid aerosol, Atmos. Chem. Phys., 7, 4237-4248, doi:10.5194/acp-7-4237-2007, 2007.

Vione, D., Maurino, V., Minero, C., Pelizzetti, E., Harrison, M. A. J., Olariu, R.-I., and Arsene, C.: Photochemical reactions in the tropospheric aqueous phase and on particulate matter, Chem. Soc. Rev., 35, 441-453, doi:10.1039/B510796M, 2006.
Wang, B. and Knopf, D. A.: Heterogeneous ice nucleation on particles composed of humic-like substances impacted by $\mathrm{O}_{3}$, J. Geophys. Res., 116, D03205, doi:10.1029/2010JD014964, 2011.

Yokelson, R. J., Crounse, J. D., DeCarlo, P. F., Karl, T., Urbanski, S., Atlas, E., Campos, T., Shinozuka, Y., Kapustin, V., Clarke, A. D., Weinheimer, A., Knapp, D. J., Montzka, D. D., Holloway, J., Weibring, P., Flocke, F., Zheng, W., Toohey, D., Wennberg, P. O., Wiedinmyer, C., Mauldin, L., Fried, A., Richter, D., Walega, J., Jimenez, J. L., Adachi, K., Buseck, P. R., Hall, S. R., and Shetter, R.: Emissions from biomass burning in the Yucatan, Atmos. Chem. Phys., 9, 5785-5812, doi:10.5194/acp-9-5785-2009, 2009.

Zahardis, J. and Petrucci, G. A.: The oleic acid-ozone heterogeneous reaction system: products, kinetics, secondary chemistry, and atmospheric implications of a model system - a review, Atmos. Chem. Phys., 7, 1237-1274, doi:10.5194/acp-7-1237-2007, 2007.

Zelenay, V., Monge, M. E., D’Anna, B., George, C., Styler, S. A., Huthwelker, T., and Ammann, M.: Increased steady state uptake of ozone on soot due to UV/Vis radiation, J. Geophys. Res., 116, D11301, doi:10.1029/2010JD015500, 2011.

Zhang, Q., Jimenez, J. L., Canagaratna, M. R., Allan, J. D., Coe, H., Ulbrich, I., Alfarra, M. R., Takami, A., Middlebrook, A. M., Sun, Y. L., Dzepina, K., Dunlea, E., Docherty, K., DeCarlo, P. F., Salcedo, D., Onasch, T., Jayne, J. T., Miyoshi, T., Shimono, A., Hatakeyama, S., Takegawa, N., Kondo, Y., Schneider, J., Drewnick, F., Borrmann, S., Weimer, S., Demerjian, K., Williams, P., Bower, K., Bahreini, R., Cottrell, L., Griffin, R. J., Rautiainen, J., Sun, J. Y., Zhang, M., and Worsnop, D. R.: Ubiquity and dominance of oxygenated species in organic aerosols in anthropogenically-influenced Northern Hemisphere midlatitudes, Geophys. Res. Lett., 34, L13801, doi:10.1029/2007GL029979, 2007.

Zhao, Z., Husainy, S., Stoudemayer, C. T., and Smith, G. D.: Reactive uptake of $\mathrm{NO}_{3}$ radicals by unsaturated fatty acid particles, Phys. Chem. Chem. Phys., 13, 17809-17817, doi:10.1039/C1CP21790A, 2011.

Ziemke, J. R., Chandra, S., Duncan, B. N., Schoeberl, M. R., Torres, O., Damon, M. R., and Bhartia, P. K.: Recent biomass burning in the tropics and related changes in tropospheric ozone, Geophys. Res. Lett., 36, L15819, doi:10.1029/2009g1039303, 2009. 